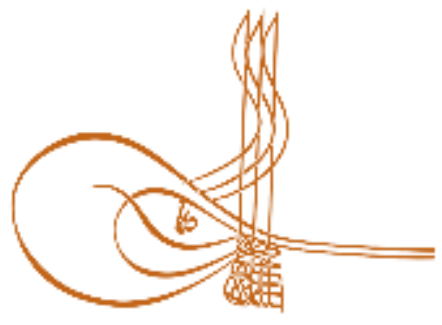

www.turkishstudies.net/social
Turkish Studies- Social Sciences

eISSN: $2667-5617$

Research Article / Araştırma Makalesi

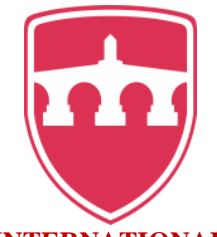

INTERNATIONAL

BALKAN

UNIVERSITY

Sponsored by IBU

\title{
Halkla İlişkilerin Kurumsal İtibar Üzerindeki Etkisine Yönelik Bir Araştırma
}

\author{
Research on Effect of Public Relations on Corporate Reputation
}

\author{
Yavuz Soykan* - Mesut Uğurlu**
}

\begin{abstract}
In today's globalized world, the diversity in products and services and ever-growing awareness of the target audience via tools such as internet and etc. have caused a competitive environment among institutions. Institutions have established the departments of public relationsin this competitive environmentto introduce their products and services to the consumers, to convey their messages to the target groups and to contribute positively to the organization where it operates with feedbacks from the target audience. The departments of public relations aim to ensure that their institutions are one step ahead in this competitive environment and to increase the reputation of the organization by increasing their customersby using various methods. Corporate reputation is the most valuable capital of an institution that can meet the expectations of all its stakeholders. In addition, It also represents the emotional and rational bonds established by social stakeholders with the relevant business and demonstrates the image that an organization has developed with all its social stakeholders. A solid corporate reputation distinguishes organizations and ensures brand loyalty enabling them to be more tolerated by the organization's target audience during difficult times. Enterprises with a good reputation can gain significant advantages by becoming the first choice of investors, customers, employees and suppliers. In this study, the impact of public relations on corporate reputation was theoretically addressed and the impact of these two concepts on each other was examined with correlation and regression analyses by conducting the survey where 128 managers and employees of Kütahya Municipality and 410 citizens from the Central District of Kütahya participated. The hypotheses for the research were tested through correlation and regression analyses and as a result of multiple regression analyses, it was found that "Promotion" and "Recognition", the dimensions of public relations, had a positive effect on corporate reputation within the scope of this study.
\end{abstract}

* Dr. Öğr. Üyesi, Dumlupınar Üniversitesi, Kütahya Uygulamalı Bilimler Fakültesi, Sigortacılık ve Risk Yönetimi Bölümü

Asst. Prof. Dr., Dumlupinar University, Kutahya Faculty of Applied Science, Department of Insurance and Risk Management

ORCID 0000-0003-0981-568X

yavuz.soykan@dpu.edu.tr

${ }_{* *}$ Astsubay, Türk Silahlı Kuvvetleri, Hava Kuvvetleri Komutanlığ 1

Air Petty Officer, Turkish Armed Forces, Air Force Command

ORCID 0000-0001-7411-3532

Cite as/ Atıf: Soykan, Y., Uğurlu, M. (2020). Halkla ilişkilerin kurumsal itibar üzerindeki etkisine yönelik bir araştırma, Turkish Studies - Social, 15(3), 1489-1526. https://dx.doi.org/10.29228/TurkishStudies.39731

Received/Geliş: 13 November/Kasım 2019

Accepted/Kabul:25 February/Şubat 2020

Checked by plagiarism software

Copyright $\mathbb{C}$ INTAC LTD, Turkey

Published/Yayın:30April/Nisan 2020

CC BY-NC 4.0 


\section{Structured Abstract: Introduction}

In today's world, economic and social changes and developments are experienced very rapidly and continuously in the environments in which organizations operate. Organizations need to keep up with this rapid change in order to maintain their existence. This can only be possible through effective and successful management. One of the success criteria in achieving the goals of the organizations is to communicate well with the environment of the organization. They need to have good relations with groups such as clients, competitors, trade unions, other institutions and organizations, the state and other public authorities, NGOs, professional organizations etc. It is getting more and more important to analyze the interests, wishes and reactions of these groups and to ensure the trust and support of these groups for the success of an organization. In this context, the departments of public relations being responsible for the communication are considered as a very important management function for the enterprises.

Organizations present information about their products and services to the target audience through the departments of public relations. Moreover, they learn the reactions from the target audience about the productions and services through the same department. The most basic responsibility of these departments is to transfer the knowledge of the goods and services to the target audience and to present the reactions to the organization. The more frequent this cycle is, the more likely it will be to attain success in public relations practices.

A positive corporate reputation requires high visibility in public. For this reason, communication is an important factor in terms of creating reputation. The public relations in the institutions is the unit performing this communication function. Therefore, there is no doubt that the effective and efficient implementation of public relations practices will contribute to the corporate reputation.

The aim of this study is to examine the importance and the consequences of the impact of public relations on the corporate reputation, to detect the interaction between them, and to determine the effect of the department on the corporate reputation by increasing the efficiency of public relations activities, especially creating an effective public relations department by the top management.

\section{Method}

This research was conducted to determine the importance and roadmap of the impact of public relations on corporate reputation and to identify interaction between them. A literature review was conducted on this subject and the approaches were tested with statistical analysis. In order to find out the impact of Public Relations on corporate reputation, a survey was conducted with the employees of Kütahya Municipality, a service organization, and to the citizens living in the Central District of Kütahya. These participants were randomly selected for the survey. The impact of public relations on corporate reputation was examined as a result of the study carried out on 128 employees and 410 citizens, the dimensions of the relationship between concepts and the impact of public relations on corporate reputation were addressed as a result of the survey.

\section{Results}

As a result of the research method, hypotheses about the effect of public relations on corporate reputation were tested and the demographic characteristics of the participants of the research were shown in the form of frequency distributions.

In order to determine the level of relationship between the recognition and promotion dimensions of public relations and corporate reputation, correlation testing was conducted and hypotheses were created by regression analysis to evaluate the effect of public relations dimensions on corporate reputation. Although the participants of the survey and the employeesworking in the municipality of Kütahya province within the time frame of the study were informed regarding the limitations of the study, the characteristics of the survey method used and it has been stated that what they have said would not be shared with their own institution and that this was an academic study, they still may have concernsthat the results of the study would be presented to the management and this could have a negative consequence for them. Therefore, the possibility of answering questions with some reservations and doubts can be accepted as a limitation of the study. The fact that the survey was conducted only in a single institution of the province can also be accepted as the limitation of the research. In the analysis evaluations, the opinions and value judgments of the employees and the public regarding the impact of public relations on corporate reputation were determined. In line with the

Turkish Studies - Social, 15(3) 
results obtained, the presence of positive relations between public relations practices and corporate reputation was observed according to the individualsparticipating in the survey.

It was observed that the relationship between public relations dimensions was higher in relation to corporate reputation than recognition, which is another dimension, at the inter-dimensional relationship level determined with the correlation analysis.

From the hypotheses in the study; By accepting the hypothesis "H1a=Recognition From Public Relations Dimensions has a positive effect on Corporate reputation." and "H1b=Promotion from Public Relations Dimensions has a positive effect on Corporate Reputation.", it has beenfound that recognition and promotion from public relations dimensions have a positive effect.

It has been observed that the impact of promotion and recognition, which are dimensions of public relations, on corporate reputation is extremely important. Because the promotion means the presentation of the activities, services, positive aspects of the organization for the target audience, in other words advertising the company. Therefore, the more importance the institution attaches to the promotion activities, the more the reputation, prestige and image on the target audience will increase in the positive way. Recognition from the public relations dimension has a low effect compared to the promotion dimensionbut still on a level to be considered by the organization. Recognition is the level of awareness by the organization's target audience. In other words, how much information the target audience knows about the organization, the organization's purpose, objectives, responsibilities, features and services provided. Hence recognition is a dimension connected to the reputation. This is because the target audience performs a better search for the organizations they consider reputable. They are more curious about the identity, characteristics, goals, activities and services. Therefore, reputation has the power to affect the organization indirectly. Briefly, organizations should pay attention to public relations activities. Because public relations activities have a close relationship with corporate reputation. And having a good reputation on the target audience is definitely among the goals of every organization. One of the most important ways to achieve this good reputation is to give importance to public relations activities and to constantly improve such activities.

\section{Conclusions and Suggestions}

As a result, although it is a well-known fact that the great capital for the institutions is their reputation, it is suggested that institutions should pay significant attention to the departments of public relations performing the communication with their target groups and their applications. Because whata language means to a person willing to maintain its existence in the most beneficial way, the public relations means the same for the institutions and organizations. While human beings try to use their language in order to express themselves in the best way, it is important for the organizations to focus on the use of public relation practices effectively and efficiently since they are also willing to express themselves in the best way. The most important way of achieving the goalsfor institutions is a good reputation and the most effective way to achieve a good reputation is a good public relations.

It is believed that the studies to be carried out on "The Impact of Corporate Social Responsibility Activities on Corporate Reputation" will be beneficial for science and the interested parties as well as for a society. The institutions and organizations have started to understand the value of corporate reputation, which is a sensitive multiplier, by giving importance to the management of corporate reputation in order to be more effective and different than their competitors. Since corporate social responsibility is a factor that can have an impact on the perception of the target audience, it is believed that understanding the importance of corporate social responsibility, increasing its applicability and carrying it out beneficially will be an important variable in gaining corporate reputation.

Keywords: Public Relations, Reputation and Corporate Reputation.

Öz: Küreselleşen günümüz dünyasında ürün ve hizmetlerde çeşitlilik, hedef kitlenin internet vb. araçlar aracılığı ile giderek bilinçlenmesi kurumlar arasında rekabet ortamının doğmasına yol açmıştır. Kurumlar bu rekabet ortamında ürün ve hizmetlerini tüketicilere tanıtmak, kurumla ilgili hedef kitleye bilgi aktarmak ve hedef kitleden gelen geri beslemelerle bünyesinde faaliyette bulunduğu kuruma katkıda olumlu girdilerde bulunması amacıyla halkla ilişkiler birimlerini oluşturmuşlardır. Halkla ilişskiler birimleri uyguladıkları birtakım metodlarla bu rekabet ortamında kurumlarının bir adım önde olmasını sağlamak ve müşteri kitlesini 
arttırarak kuruluşun itibarını arttırmayı hedeflemektedirler. Kurumsal itibar; bir kurumun tüm paydaşlarının beklentilerinin karşılanabileceği ve o kurumun sahip olması gereken en değerli sermayesidir. Ayrıca, sosyal paydaşların ilgili işletmeyle kurdukları duygusal ve rasyonel bağları temsil etmekte ve bir örgütün tüm sosyal paydaşları ile geliştirdiği imajını göstermektedir. Sağlam bir kurumsal itibar, örgütleri birbirinden ayırmakta ve aynı zamanda marka sadakati sağlayarak zor zamanlarda kurumun hedef kitlesi tarafindan daha fazla tolere edilmesine olanak sağlamaktadır. İyi bir İtibarı olan işletmeler yatırımcıların, müşterilerin, çalışanların ve tedarikçilerin ilk tercihi haline gelerek önemli avantajlar elde edebilmektedirler. Bu çalışmada halkla ilişkilerin kurumsal itibar üzerindeki etkisine teorik olarak değinilmiş ve Kütahya Belediyesinde toplam 128 yönetici ve çalışan ile Kütahya Merkez İlçede yaşayan 410 vatandaşın katılımıyla yapılan anket çalışması ile bu iki kavramın birbiri üzerindeki etkisi korelasyon ve regresyon analizleriyle incelenmiştir. Bu çalışma kapsamında araştırma için oluşturulan hipotezler, korelasyon ve regresyon analizleri yardımıyla test edilmiş ve çoklu regresyon analizi sonucunda kurumsal itibar üzerinde halkla ilişkiler boyutlarından "Tanıtma" ve "Tanıma", boyutlarının pozitif etkisinin olduğuna ulaşılmıştır.

Anahtar Kelimeler: Halkla İlişkiler, İtibar ve Kurumsal İtibar.

\section{Giriş}

Çağımızda yaşanan hızlı gelişmeler birey olarak sosyal hayatımızda etkin olarak hissedildiği gibi tüm kurum ve kuruluşlarda da etkin bir şekilde kendini göstermektedir. Kurum ve kuruluşlarca yaşanan teknolojik değişmelere ayak uydurulmaya çalışılmakta ve buna bağlı olarak yönetim ve uygulamalarda yeni teknik ve yöntemlere başvurulmaktadır.

Bir yönetim uygulaması olan halkla ilişkiler bilhassa iletişim teknolojilerinde yaşanan hızlı gelişmelere bağlantılı olarak önemini gittikçe arttıran bir disiplin haline gelmiştir. Günümüzde birçok kurum ve kuruluş bünyesinde halkla ilişkiler birimini bulundurma zorunluluğu hissetmektedir. Çünkü iletişim alanındaki bu gelişmeler kurum ve kuruluşların hedef kitleleriyle daha sık iletişim içinde bulundurmalarını gerektirmektedir. Halkla ilişkiler birimleri kurum ve kuruluşların faaliyetleri ile ilgili iç ve dış paydaşlara bilgi aktarırken, yine iç ve dış paydaşların algı ve beklentileri ile ilgili bilgileri kuruma aktararak bu iletişim diyalogunu gerçekleştirmektedirler.

Günümüzde farklı iş alanlarında çok sayıda benzer üretim yapan veya hizmet veren kurum ve kuruluşlar bulunmaktadır. Dolayısıyla aynı iş alanında aynı üretimi yapan veya hizmeti veren bu kurumlar arasında rekabet kaçınılmaz olmaktadır. Giderek kalabalıklaşan çevrede insanların beklenti, ilgi ve ihtiyaçları da sürekli değişmektedir. Gün geçtikçe zorlaşan bu rekabet ortamında varlıklarını sürdürmek isteyen kurum ve kuruluşların hitap ettikleri hedef kitleler ile sağlıklı bir iletişim kurma zorunlulukları bulunmaktadır. Hedef kitleye hızlı ve sağlıklı bir şekilde ulaşabilmek için kurum ve kuruluşların dikkatleri üzerlerine çekmeleri gerekmektedir. Bu dikkat çekmenin en etkin yolu ise hedef kitle algisında olumlu bir yer edinme ile ilgilidir.

Kurum ve kuruluşlar kendi çevrelerinde olumlu bir algı oluşturabilmeleri için sahip olmaları gereken birtakım unsurlar bulunmaktadır. Bu sahip olunması gereken unsurlar güçlü bir kurum kimliği, sağlam bir kurumsal kültür, iyi bir kurumsal imaj ve kurumsal sosyal sorumluluktur. $\mathrm{Bu}$ açıklanan unsurların tamamı kurumsal itibar çatısı altında birleşmektedirler. Yani kurum ve kuruluşların hedef kitle üzerinde olumlu bir etki, algılarında pozitif bir imaj oluşturmaları için kurumsal itibar kavramına önem vermeleri son derece önemli bir husustur.

Halkla ilişkiler birimleri bünyesinde faaliyet gösterdikleri kurum ve kuruluşların faaliyetlerini, ürün ve hizmetlerini, gerçekleştirdikleri ve gerçekleştirmeyi planladıkları sosyal sorumluluk projelerini hedef kitlelere aktarmaktadırlar. Bu da bize şunu göstermektedir ki kurumsal itibarın büyük bir kısmı halkla ilişkiler faaliyetleri ile oluşturulmaktadır. Burada şu görülmektedir; halkla ilişkilerin etkin ve verimli bir şekilde uygulanması kurumsal itibara olumlu katkıda bulunmaktadır. Oluşan bu olumlu kurumsal itibar ise kurum ve kuruluşlara maddi ve manevi kazançlar sağlayacaktır.

Turkish Studies - Social, 15(3) 
Kurumsal itibar, uzun süren çabalar neticesinde elde edilmesine karşın, bir anda kaybedilen bir değerdir. Bu özelliğinden dolayı kurumsal itibarı yönetmek ve daima elde tutmak oldukça zordur. Burada hakla ilişkiler birimlerine çok önemli sorumluluklar yüklenmektedir.

$\mathrm{Bu}$ çalışmanın amacı halkla ilişkilerin kurumsal kimlik, kurumsal imaj, kurumsal kültür, kurumsal sosyal sorumluluk gibi unsurlardan oluşan kurumsal itibara etkisini bütüncül açıdan ele alarak, halkla ilişkiler uygulamalarının kurum ve kuruluşlarca nasıl bir öneme sahip olduğunu ortaya koymaktır.

\section{Literatür İncelemesi}

\subsection{Halkla İlişkiler}

Halkla ilişkiler kavramı incelendiğinde literatürde halk; ortak ilgi veya özelliğe sahip insanlardan oluşan grup olarak tanımlanmaktadır. Halk kelimesi kullanıldığı zaman genellikle akla yönetilen topluluklar gelmektedir. İlişkiler kavramı ise yine literatürde iletişimle yürütülen ve en az iki tarafı ilgilendiren amaçlı faaliyet olarak tanımlanmıştır. Halk ve ilişkiler terimleri beraber okunduğunda halk topluluğu ile olan ilişkiler anlamı ortaya çıkmaktadır.

İnsanlığın var oluşu ile başlayan halkla ilişkiler, insanların toplum olarak yaşamaya başlamalarıyla giderek kendini hissettiren bir faaliyet olarak gelişmiştir. Bir kavram olarak ilk defa Thomas Jefferson (1807) tarafindan bağımsızlık bildirisinde kullanılmış ve zamanla yöneten ve yönetilen ilişkisinin ortaya çıkması nedeniyle halkla ilişkiler etkin bir araç haline dönüşmüştür.

Halkla ilişkilerin süreç içerisinde ortaya çıkması ve önem kazanmasında bazı sebeplerin varlığı şüphesiz bir gerçektir. İdeolojik devlet faaliyetlerinin önemini bilen günümüz az gelişmiş devlet yöneticileri, halkı ideolojik araçlar kullanarak denetim altında tutmaya çalışmakta ve düzenin halk tarafından olumlu değerlendirilmesini sağlamak için halkla ilişkileri bir araç olarak kullanmaktadır. Yönetsel etkinliğini artırma zorunluluğu hisseden yöneticiler de halkla sorumluluğu paylaşmakta, yapılan işleri halka anlatma ve tüm kesimlerin oylarını öğrenmek için halkla ilişkiler faaliyetlerine başvurmaktadırlar. Yönetimin karmaşıklaşması sonucu ortaya çıkan güçlükleri yok etmek için de halkla ilişkilerden yararlanılmaktadır. Kuruluşlarla toplum arasında karşılıklı güvene dayalı ilişkiler geliştirme zorunluluğu da halkla ilişkilerin gelişmesinde etkili olmuştur. Bunun yanında halkla ilişkilerin demokratikleşme, demokratik hakların kazanımı ile eş zamanlı geliştiği görülmektedir. Teknolojik gelişmeler ve kitle iletişim araçlarının gelişimi örgütlere toplumdan izole olma firsatı vermemektedir. Örgütler topluma kendilerini tanıtmak ve toplum nezdinde olumlu imaja sahip olmak için halkla ilişkiler faaliyetlerine başvurmaktadırlar. Modernleşme sürecinin hız kazanması ve iletişim araçlarının gelişimi ile farklı etnik ve siyasi grupların ortaya çıktığ bunların toplum içinde bir bütünlük arz etmesi konusunda da halkla ilişkilerden yararlanılmıştır. Diğer yandan meşrutiyet sorunu yaşamak istemeyen her örgüt varlığına haklı gerekçeler bularak sosyolojik anlamda meşrutiyet elde etmek için de halkla ilişkilerden yararlanmaktadır. Rekabet olgusunun küreselleşmesi de halkla ilişkilerin önemini artıran diğer önemli bir faktör olarak karşımıza çıkmaktadır (Erdem ve Akbaba, 2007:188).

Geçmişten günümüze kadar halkla ilişkilerin özünü yakalamaya çalışan birçok tanım bulunmaktadır. Bu yapılan tanımlara kısaca bakacak olursak;

İngiltere Halkla İlişkiler Enstitüsü (IPR), halkla ilişkileri "Bir kuruluş ile hedef kitlesi arasında iyi niyet ve karşılıklı anlayışa dayalı ilişkileri sürdürmeye yönelik, önceden planlanmış çabalar olarak tanımlamaktadır(Peltekoğlu, 1993: 5).

Halkla ilişkiler; yönetimin felsefesi, bu felsefenin yürütülen politika ve eylemlerle görüntülenmesi, bu yönetim fonksiyonu ve karşılıklı anlayış ve iyi niyetin sağlanması için, 
kamuoyu ile haberleşme yöntemlerinden yararlanılarak bu felsefenin, politikanın, uygulamanın ve eylemlerin açıklanmasıdır(Asna, 1998: 2).

Uluslararası Halkla İlişkiler Birliği, halkla ilişkiyi, özel veya kamu kesimlerinde faaliyet gösteren bir kuruluş veya kurumun, ilişkide bulundukları kimselerin anlayış, sempati ve desteğini elde etmek üzere sürekli olarak yapmış oldukları bir yönetme görevi olarak tanımlamıştır. Bu tanımlamaya göre halkla ilişkiler (Tortop, 2003: 13):

i. En verimli bir haberleşme sistemini kurmak,

ii. Kurum veya kuruluşlar içinde beşerî ilişkiler alanında en büyük ölçüde sempati yaratmak,

iii. Bir faaliyet hakkında en kapsamlı bilgileri sağlamak amacını gütmektedir.

Kavram üzerinde görüş birliğine varılamamış olması, Foundation for Public Relations Research and Education'u geniş çaplı bir araştırma yapmaya yöneltmiş, bu çalışmada, halkla ilişkiler kavramının çevresel faktörler ve son yetmiş beş yılda yaşanan değişimlerden nasıl etkilendiği araştırılmıştır. Altmış beş uzmanın yaptığı çalışmanın sonucunda saptanan, 472 tanımın analizi 1şı̆̆ında varılan tanıma göre, halkla ilişkiler, "bir işletme ile hedef kitle arasında karşılıklı iletişimi, anlayışı, oluşturmaya ve sürdürmeye yardımcı olan ayrıcalıklı bir yönetim görevidir." şeklinde yorumlanmaktadır (Peltekoğlu, 2007: 2-3).

Sosyologlar kitlelere bir şey yaptırabilmek için üç etkili yol bulunduğundan söz etmektedirler. Bunlar, zor kullanmak, para ile satın almak ve inandırmaktır. Halkla ilişkiler sanatının kullandığı yol ise bunlardan üçüncü yol olan "inandırmak" kavramıdır. Çağımızda kamuoyunun görüşü önemli bir etken olduğundan dolayı halkın inanmadığı ve desteklemediği bir şeyi gerçekleştirmek zor bir durum olarak görünmektedir. Bu nedenle kamuoyunun görüş ve inançlarındaki değişimler yakından izlenmeli; kişilerin örgütlerin davranış ve tutumları siyasi politikalar buna göre ayarlanmalıdır. Halkla ilişkiler konusunun hızla yayılan ve bu işte çalışanların her y1l birkaç kat çoğaldığı bir meslek haline geldiği ülkelerin; eğitim oranı yüksek, örgütlenmiş bir kamuoyunun söz sahibi olduğu ülkeler olması bir rastlantı değil bu önemin bir kanıtıdır. Buna karşılık, düzenli bir kamuoyundan yoksun, eğitim oranı düşük, halk arasındaki düşünüşlerin anlaşmadığı ülkelerde "Halkla ilişkiler" hiç duyulmamış, ilgilenilmemiş bir deyimdir. O halde işlerin halk tarafından yürütüldüğü, bir başka deyimle halkoyunun her alanda ağırlığını duyurduğu ülkelerde kuruluşlar ve hükümetler halkla iki yönlü ilişki kurma zorunluluğu duymuşlar; halkın henüz sesini duyuramadığı, boynunu bükerek yönetilmekten kurtulamadığı ülkelerde ise bu zorunluluk ortaya çıkmamıştır. Açıktır ki bu farklı durum, iktisadi düzenlerin sonucundan başka birşey değildir. Kalkınma çabasındaki ülkelerde iktisadi durum düzelirken kamuoyunun da aydınlanması umulacağına göre, bu durumdaki ülkelerin de ileri ülkeler gibi halkla ilişkiler konusunda daha kalkınmanın başındayken eğilmeleri gerekmektedir (Asna, 1998: 26-27).

Halkla ilişkiler işletmelerin ve kurumların en önemli fonksiyonlarından biri olarak karşımıza çıkmaktadır. Çünkü işletmelerin önemli kararlar almasında sosyal fayda sağlayabilmeleri için halkla ilişkiler birimlerine ihtiyaçları bulunmaktadır. İşletmeler kamuoyunu pozitif yönde etkilemek ve kalıcı izler bırakmak peşindedirler. Kamuoyunu olumlu yönde etkileyen işletmeler tüm paydaşlarının hafizalarında olumlu bir itibar oluşturmaları daha mümkün görülmektedir. Bu da işletmelerin tercih edilmesinde en önemli faktörlerden birisi olarak karşımıza çıkmaktadır(Bakır, 2015:8).

Sonuç olarak halkla ilişkiler gerek politik alanda olsun gerek bazı meslek gruplarında çalışan kişiler için olsun, gerek işletmeler için gerek kamu kurumları için sağladığı olumlu faydalar nedeniyle önemini giderek arttıran bir kavram olmaya hızlı bir şekilde devam etmektedir. 


\subsubsection{Halkla İlişkiler}

Halkla ilişkilerde genel amaç, bir anlamıyla örgüt ile dış çevre arasında sürekli iyi ilişkiler kurmak ve geliştirmektir. Halkla ilişkiler bu anlamda örgütün yalnız halkla olan ilişkilerini değil, diğer örgüt veya topluluklarla olan ilişkilerini de kapsamına almaktadır. Halkla ilişkiler sayesinde örgütün diğer örgütlerle ilişkilerinin iyileştirilmesi ve bu bağlamda iyi bir ortam yaratılması sayesinde örgütün iş verimin artması sağlanacak ve örgütün gelişmesine etkisinin önemi artacaktır(Tortop, 2003:19).

Halkla ilişkilerin amaçları genel olarak aşağıdaki gibi özetlenebilmektedir (Budak ve Budak, 2004:9-10):

i. Halka örgüt ve yönetim hakkında bilgi vererek, örgütün politika ve çalışmalarını benimsetmek, yönetime karşı halkta olumlu tutum ve davranışlar geliştirmek,

ii. İlgili kişi ve kurumlarla etkileşime girerek onların desteğini almak,

iii. Hedef kitlelerden bilgi alarak daha sağlıklı ve sürekli ilişkiler kurmak ve dolayısıyla çevreyle ilgili kararların etkinlik ve verimliliğini arttırmak,

iv. Topladığı bilgi ve verilerle mal veya hizmetlerini geliştirerek işletmeye ve topluma faydalı hale gelmek ve halkın işbirliğini sağlayarak daha uygun hizmetlerin daha kolay ve çabuk götürülmesini gerçekleştirmek,

v. Örgütün genel çevresine karşı sosyal sorumluluk duygusunu arttırmak, toplumun ve yönetimin ahlaki değerlerini korumaktır.

\subsubsection{Halkla İlişkiler Modelleri}

Halkla ilişkilerin pratikte kendisini gösterdiği birtakım modelleri bulunmaktadır. Aşağıdaki tabloda bu modeller ile halkla ilişkilerin amacı ve yapısı, amacı doğrultusunda gösterdiği iletişim tarzı, kullandığı alanlar ve temsilcileri gösterilmektedir. 
Tablo 1: Grunig ve Hunt’a Göre Halkla İlişkiler Davranışının Dört Modeli

\begin{tabular}{|c|c|c|c|c|}
\hline & Model 1 & Model 2 & Model 3 & Model 4 \\
\hline Karakteristiği & $\begin{array}{l}\text { Basın } \\
\text { Ajansi/Tanıtım } \\
\text { Publicity } \\
\end{array}$ & $\begin{array}{l}\text { Kamuyu } \\
\text { Bilgilendirme }\end{array}$ & $\begin{array}{l}\text { İki Yönlü } \\
\text { Asimetrik }\end{array}$ & İki Yönlü Simetrik \\
\hline Amaç & Propaganda & $\begin{array}{l}\text { Gerçek bilgilerin } \\
\text { yayılması }\end{array}$ & $\begin{array}{l}\text { Bilimsel analiz } \\
\text { temel üzerinde } \\
\text { ikna }\end{array}$ & Karşılıklı anlayış \\
\hline $\begin{array}{l}\text { Organizasyonun } \\
\text { Hedefi/Kurumsal } \\
\text { Amacı }\end{array}$ & $\begin{array}{l}\text { Kamuoyunun, } \\
\text { çevrenen } \\
\text { kontrolü, } \\
\text { hakimiyeti }\end{array}$ & $\begin{array}{l}\text { Kamunun } \\
\text { kazanılması } \\
\text { /çevresel } \\
\text { adaptasyon, işbirliği }\end{array}$ & $\begin{array}{l}\text { Kamuoyunun } \\
\text { çevrenin konrolü, } \\
\text { hakimiyeti }\end{array}$ & $\begin{array}{l}\text { Kamuoyu ile uyum } \\
\text { çevresel kadaptasyon }\end{array}$ \\
\hline $\begin{array}{l}\text { Halkla İlişkilerin } \\
\text { Rolü }\end{array}$ & Danışma & Bilgilerin yayılması & Danışma & Aracılık \\
\hline İletişimin Doğası & $\begin{array}{l}\text { Tek yönlü, tam } \\
\text { gerçek önemli } \\
\text { değil }\end{array}$ & $\begin{array}{l}\text { Tek yönlü, gerçek } \\
\text { önemli değil }\end{array}$ & $\begin{array}{l}\text { Çift yönlü, } \\
\text { dengesiz etki }\end{array}$ & $\begin{array}{l}\text { Çift yönlü, dengeli } \\
\text { etki }\end{array}$ \\
\hline İletişim Modeli & $\begin{array}{l}\text { Kaynaktan } \\
\text { alıciya }\end{array}$ & Kaynaktan alıcıya & $\begin{array}{l}\text { Kaynaktan alıcıya } \\
\text { feedback }\end{array}$ & $\begin{array}{l}\text { Gruptan gruba } \\
\text { feedback }\end{array}$ \\
\hline $\begin{array}{l}\text { Araştırmanın } \\
\text { Doğası }\end{array}$ & $\begin{array}{l}\text { Çok önemli } \\
\text { değil }\end{array}$ & Çok önemli değil & $\begin{array}{l}\text { Halkla ilişkiler } \\
\text { kampanyalarından } \\
\text { önce ve sonra } \\
\text { tutumların kontrol } \\
\text { edilmesi }\end{array}$ & $\begin{array}{l}\text { Kamu ile } \\
\text { organizasyon } \\
\text { arasında karşılıklı } \\
\text { anlayışın } \\
\text { değerlendirilmesi }\end{array}$ \\
\hline Tipik Temsilcisi & P.T.Barnum & Ivy Lee & $\begin{array}{l}\text { Edward } \\
\text { L.Bernays }\end{array}$ & $\begin{array}{l}\text { Bernays, Halkla } \\
\text { ilişkiler eğitimcileri } \\
\text { ve meslek dernekleri }\end{array}$ \\
\hline $\begin{array}{l}\text { Günümüzde } \\
\text { uygulandığı } \\
\text { alanlar }\end{array}$ & $\begin{array}{l}\text { Spor, tiyatro, } \\
\text { satış geliştirme }\end{array}$ & $\begin{array}{l}\text { Hükümetler, } \\
\text { belediyeler, kar } \\
\text { amacı gütmeyen } \\
\text { kuruluşlar, } \\
\text { dernekler, iş } \\
\text { dünyası }\end{array}$ & $\begin{array}{l}\text { Serbest ekonomi, } \\
\text { ajanslar }\end{array}$ & $\begin{array}{l}\text { Sosyal amacı olan iş } \\
\text { dünyası, ajanslar }\end{array}$ \\
\hline $\begin{array}{l}\text { Yüzdesel olarak } \\
\text { yaygınlık } \\
\text { (ABD'de } 1984 \\
\text { Yılında) }\end{array}$ & $\% 15$ & $\% 50$ & $\% 20$ & $\% 15$ \\
\hline
\end{tabular}

Kaynak: Okay, A., ve Okay, A., 2005: 83.

Halkla ilişkilerin tarihsel gelişimi ile paralel olarak şekillenen Grunig ve Hunt'ın dört halkla ilişkiler modeli (Basın ajansı modeli, kamuoyu bilgilendirme modeli, iki yönlü asimetrik model, iki yönlü simetrik model) bugün halen çeşitli kurumlarca dikkate alınarak uygulanmaktadır. Basın ajansı ve kamuoyu bilgilendirme modellerinde basına yönelik yapılan faaliyetler halkla ilişkiler olarak ifade edilmiştir. İki yönlü simetrik ve asimetrik modellerde ise daha gelişmiş ve profesyonel halkla ilişkiler uygulamaları olarak nitelendirilebilecek bir anlayış mevcuttur. Modellerin seçimi işletmenin içinde bulunduğu kurum kültürüne göre şekil almaktadır. Farklı 
kitlelere farklı halkla ilişkiler sorunları için duruma uygun model kullanılmaktadır (Aydın, 2012: 71).

Basın Ajansı Modeli:Bu modelin en tanınmış temsilcisi P.T.Barnum'dur. Bu modelde halk1 kazanmak ve etkilemek için dürüst olsun veya olmasın her türlü uygulamadan yararlanılmaktadır. Basın ajansları, seslerini ilk olarak ucuz ve haber değeri olmayan basını temsil eden Penny Press Gazetesi ile duyurmuşlardır. Bunların, müşterilerini gündemde tutabilmek için kullandıkları en büyük koz flaş haberlerdir. Bu sebepten ötürü Barnum da birçok kutlama töreni düzenlemiş, bunları yaparken de gazetelere reklam için para ödemeyip, bu gazetelerde abartıl1, sansasyonel haberlerle yer almıştır (Ülger, 2003:13).

Kamuoyunu Bilgilendirme Modeli: Grunig ve Hunt'ın tanımladığı modellerden kamuoyu bilgilendirme modeli, benzer bir şekilde basın ajansı tanıtım modeli gibi halkla ilişkilerin teknisyen rolünün ağır bastığı amaçsız halkla ilişkilerdir. Kamuoyu bilgilendirme modelinin gelişmesinde 20 . Yüzyılın başlarında demiryolu, bankacılık, petrol, emlak, tütün, demir-çelik ve finans alanlarında söz sahibi olan çeşitli iş adamları ve onların faaliyetlerinin toplum üzerindeki olumsuz etkilerine yönelik yazılar yazan gazeteciler etkili olduğu söylenmektedir (Erdoğan, 2005:339).

Çift Yönlüi Asimetrik Modeli: Grunig ve Hunt (1984)'ın 1920lerden sonraki halkla ilişkiler uygulamalarını tanımladığı iki yönlü asimetrik model, Amerikan halkının kamuoyunun gücünü fark edip, kendi istekleri ve ilgilerini vurguladıkları bir dönemin uygulamasıdır. Ticari örgütler ve kar amacı gütmeyen kuruluşlar, kamuoyunu anlamanın ve kurumsal sorumluluğa olan ihtiyacın öneminin farkına varmışlardır. Benzer şekilde hükümet kuruluşları da bünyelerinde halkla ilişkileri uygulayacak uzman personel çalıştırmaya başlamışlardır (Freitag ve Stones, 2009: 23).

Çift yönlü asimetrik modelin amacı, bilimsel verilere dayanarak bir ikna gerçekleştirmektir. Burada anlaşılması gereken, tutum ve davranışlar hakkında sosyolojik teorilerin ve araştırma sonuçlarının, halkla ilişkiler kampanyalarının ileteceği mesajları daha anlaşılır ve şeffaf hale getirmek amaciyla kullanılmasıdır. (Okay, Okay, 2005: 122-123):

Çift Yönlüi Simetrik Modeli: İki yönlü simetrik model, hem örgütün hem de hedef kitlenin tutum ve davranışlarında gerekli değişiklikler için kullanılabilecek müzakere ve çatışma çözme stratejilerini içeren halkla ilişkiler programlarını içerir. Bu model de yine iki yönlü bir bilgi alışverişi söz konusu olup bu kez geri bildirim örgütün kendi toplumdan gelen istek ve taleplere uyarlaması yönünde bir değişim çabasına yol gösterir. Burada amaç karşılıklı anlayış ve haklara saygidır (Oktay, 2002: 73).

İlk üç modelde halkla ilişkilerin rolü ve iletişim yapısı sırasıyla danışma, tek yönlü, gerçek ve araştırma önemsiz; bilgilerin yayılması, tek yönlü, gerçek önemli, araştırma önemsiz; danışma, çift yönlü dengesiz etki, pre-post tutum araştırmaları üzerine yoğunlaşırken, iki yönlü simetrik modelde halkla ilişkilerin rolü aracılıktır, iletişimin yapısı çift yönlü ve dengeli etkiye sahiptir, kamuoyu ile örgüt arasında interaktif işleyiş̧e olanak sağlayacak esnek yönetim prensipleri söz konusudur. Simetrik halkla ilişkiler modelinin özü her iki tarafın onaylayacağı sonuçlara ulaşmaktır (Kuş, 2008:34).

\subsection{Kurumsal İtibar}

Kurumsal itibar kavramı; çalışanların, yatırımcıların, tedarikçilerin, müşterilerin, yöneticilerin, kredi verenlerin, medyanın ve de toplumun işletmenin ne olduğuna dair olumlu veya olumsuz, güçlü veya zayıf vb. hisler ve etkileyici tepkilerini ifade etmektedir (Chun, 2005: 98).

Son zamanlarda hem ülkemizde hem de dünyada çeşitli işletme türleriyle ilgili olarak (özel, kamu, kar amacı olmayan kurumlar) yolsuzluk haberleri, nepotizm, yaşanan skandallar daha sık duyulur olmuştur (Ergun, 2012: 226). 
Kurumsal itibar ile ilgili olarak geçmişten günümüze birçok tanımlama yapılmıştır. Uluslararası alanda yapılan ve kabul gören birtakım tanımlamalardan bazıları Tablo 2'de belirtilmiştir.

Tablo 2: Kurumsal İtibarın Uluslararası Alanda Kabul Gören Birtakım Tanımları

\begin{tabular}{|c|c|}
\hline ARAŞTIRMACILAR & TANIMLAR \\
\hline Weigelt ve Camerer & Bir kuruma yüklenen ve geçmişteki davranışlardan çıkarılan özellikler bütünü. \\
\hline \multicolumn{2}{|l|}{1988} \\
\hline Teece vd. 1997 & $\begin{array}{l}\text { Kurumun pazarda çeşitli amaçlarını gerçekleştirmesine olanak sağlayan soyut } \\
\text { değer. }\end{array}$ \\
\hline $\begin{array}{l}\text { Carmeli ve Cohen } \\
2001\end{array}$ & $\begin{array}{l}\text { Soyut bir değerdir, kurumun şu anki değerleri, pozisyonu ve gelecekteki } \\
\text { davranışı hakkında bir çeşit istatistiki özeti temsil etmektedir. }\end{array}$ \\
\hline Passow vd. 2003 & $\begin{array}{l}\text { Müşterilerin, çalışanların, yatırımcıların ve genel olarak kamuoyunun kurumla } \\
\text { ilgili iyi ya da kötü, zayıf ya da güçlü etkileyici veya duygusal tepkileri. }\end{array}$ \\
\hline $\begin{array}{l}\text { Rose ve Thomsen } \\
2004\end{array}$ & $\begin{array}{l}\text { İnsanların algılamalarının yansımasıdır. Bu algılamalar, kurumun geçmiş̧eki } \\
\text { davranışlarına dayanak oluşturmaktadır. }\end{array}$ \\
\hline Clardy 2005 & Kurumun hem dışındaki hem de içindeki insanların imajı ya da betimlemesi. \\
\hline $\begin{array}{l}\text { Aqueveque ve Davide } \\
2007\end{array}$ & $\begin{array}{l}\text { Geçmişteki hareketlerden çıkarılan ve kuruma atfedilen nitelikler bütünüdür ve } \\
\text { geçmişteki davranışların sonucu olarak kuruma atfedilen özelliklerin toplamıdır. }\end{array}$ \\
\hline Fombrun 2007 & $\begin{array}{l}\text { Kurumsal itibar; paydaşların kurumla kurduğu duygusal ve akılcı bağları, } \\
\text { kurumun tüm paydaşlarındaki imajının net tanımlamasıdır. }\end{array}$ \\
\hline
\end{tabular}

Kaynak: Gümüş, Öksüz, 2009a: 4-5.

Kurumsal itibar; bir kurumun tüm paydaşlarının beklentilerinin karşılanabileceği ve o kurumun sahip olması gereken en değerli sermayesidir. Ayrıca, sosyal paydaşların ilgili ișletmeyle kurdukları duygusal ve rasyonel bağları temsil etmekte ve bir örgütün tüm sosyal paydaşları ile geliştirdiği imajını göstermektedir. Sağlam bir kurumsal itibar, örgütleri birbirinden ayırmakta ve aynı zamanda marka sadakati sağlayarak zor zamanlarda kurumun hedef kitlesi tarafindan daha fazla tolere edilmesine olanak sağlamaktadır. İyi bir İtibarı olan işletmeler yatırımcıların, müşterilerin, çalışanların ve tedarikçilerin ilk tercihi haline gelerek önemli avantajlar elde edebilmektedirler. Örneğin, müşteriler nezdinde kazanılan kurumsal itibar; marka değerini artırmakta, sadakati sağlamakta, yeniden satın almaya teşvik etmekte ve dolayısıyla daha fazla kazanç sağlanmasına neden olmaktadır. Aynı şekilde çalışanlar nezdinde sağlanan kurumsal itibar; mevcut çalışanların niteliği daha iyi yeni çalışanları çekmesine, karlılığın ve üretimin yükselmesine önemli ölçüde katkı sağmaktadır (Karaköse, 2007: 38-42).

Kurumsal itibar yönetiminin temelinde tutarlılık, bütünsellik, sürdürülebilirlik ve kalıc1lık yer almaktadır. Kurumsal itibar yönetiminin etkin olarak sağlanması için örgüt tarafından ilk olarak kendi konumlandırmasına yönelik paydaşlarını (müşteriler, hissedarlar, toplum, çalışanlar, tedarikçiler vs.) ve onların istek ve beklentilerinin net olarak belirlenmesi gerekmektedir. Kurumsal itibarı kurumsallaştırmak ve korumak için ahlaki standartlara her şeyden fazla önem verilmesi gerekmektedir (Genç, 2012: 314).

Kurumsal itibar üzerinde sıklıkla durulan bir kavram olarak literatürde karşımıza çıkmaktadır. Çeşitli araştırmacılar tarafından farklı yaklaşımlarla araştırılan kurumsal itibar, Dhir ve Vinen tarafından bazı yaklaşımlarla tasnif edilmektedir (Eğinli, 2008: 54-55): 
Kolektif Yaklaşım: Kurumsal itibar yönetimi, kurumun paydaşlarında yüksek düzeyde bir saygınlığın oluşturulması ve bu saygınlığın devam ettirilmesi olarak belirtilmektedir. Kurumsal itibar, işletmenin geçmişindeki performansı ve davranışlarına ilişkin göstergeler aracılığıyla farklı paydaşlara sunulan değerin kolektif bir değerlendirmesi olarak ifade edilmektedir. Diğer bir deyişle kurumsal itibar, kurumun paydaşlarının örgüt hakkında oluşturdukları ortak izlenimlerden oluşmaktadır.

İletişim Yaklaşımı: Kurumsal itibar, kurumsal kimlik ile yakın anlama gelmektedir. Kurumsal itibar yönetimi, kurumun finansal ve stratejik başarılardan etkilenen paydaşlardan elde edilen pozitif geri bildirimler ve örgütün pozitif bir algıya sahip olması olarak açıklanmaktadır. $\mathrm{Bu}$ yaklaşım ekonomik rasyonelliğe dayanmaktadır. Kurumun paydaşlarının kurumdan beklentileri kurumsal itibar yönetimini etkilemekte ve pragmatik bir iletişim yöntemi izlenmektedir.

Karar Verme Yaklaşımı: İtibar, kurumun finans, insan vb. kaynaklarının verimli ve etkili bir şekilde kullanılmasına karar verilmesi ile kazanılmaktadır. Karar verme metodları kurumsal itibar yöntemlerinin uygulanmasında belirleyici olmaktadır. Kurumun karar verme yöntemi, pazar seçimi ve proje yatırımları gibi kararlarındaki başarısını belirlemektedir. Kurumsal itibar yönetimi kurumda belirli birimlerdeki karar vericilerin bu süre zarfında yer alması ile gerçekleştirilebileceği düşünülmektedir.

Finansal Yaklaşım: Kurumsal itibar, işletmenin yatırımcılara, pazarlara ve medyaya olan yanıtlarını hatırlatan birtakım faktörlerin belirlenmesini ifade etmektedir. Bir işletmenin pazarlara borç ya da kazanç, yatırımcılara riskler ve kar paylarını, medyaya kamunun ilgisi, kurumsal skandallar, kurumun kazançları vb. yanıtların iletilmesini içermektedir. Kurumların sağlam bir itibara sahip olması finansal performanslarının başarısına bağlı olmaktadır.

Anlaşma Yaklaşımı: İtibar, karşılıklı güven temelinde oluşturulan anlaşmaya bağlı olmaktadır. Kurumsal itibar, paydaşların çalışmayı tercih ettikleri kurum ile yasal gereklilikleri gerçekleştirmeye bağlı olarak gelişmektedir.

Yansıtıcı Yaklaşım: İtibar, taraflar arasındaki ilişki temelinde gelişmekte ve güvene dayanmaktadır. İşletme ve hedef kitleleri arasındaki iletişim sadece kurumun oluşturduğu imaj, hedef kitle ile iletişim biçimi ve davranış tarzı ile sınırlı kalmaması gerekmektedir. Kurumsal itibarın yönetimi, kurumsal vatandaşlık, liderlik, kurumsal sosyal sorumluluk vb. kurumun toplum ile değer temelli çalışanları tarafindan talebinin artması olarak ifade edilmektedir.

Sonuç olarak bir işletmenin başarısının o kurumda çalışanların başarısı ile doğru orantılı olduğu kabul edilirse özellikle çalışanlar ve kurum faaliyetlerinin devam ettirilmesinde önemli bir katk1 ve fayda sağlayan tepe yönetimin yüksek nitelikli kişilerden seçilmesi, kurumsal itibarın artmasına ve kalıcı olmasına önemli ölçüde katkı sağlamaktadır (Ordu;2015:64).

Halkla ilişkiler kapsamında, halkla ilişkiler olgusunun ortaya çıktığı ve geliştiği yıllardan bugüne kadar itibar/kurumsal itibar kavramları ile ilgili olarak birçok tanımlama ve araştırma yapılmıştır. İşletmelerde verimli üretimin ve başarının temel noktası çalışanların bir müşteri gibi memnuniyetini sağlamasıdır. (Demirci ve Güler, 2015; 747)

Son yıllarda bilim ve teknoloji alanında yaşanan değişimler küresel kapsamda ulaşılabilir bir bilgi havuzu oluşturmuş ve bu yaşanan gelişmelerin yansımaları sonucunda arz ve talep maksimum seviyelere ulaşmıştır. Bu hızlı gelişmelerin merkezinde kalan ve sürekli bir rekabetle karşı karşıya kalmak zorunda olan kurumlar pazarlama, satış, üretim, yönetim sistemleri, lojistik gibi örgütün yönetsel alanındaki beklentileri karşılamak ve gelişmeleri takip ederek güncel yönetim tarzlarını anlamak ve uyum sağlamak durumunda kalmışlardır. Bu doğrultuda günümüzde uygulamacı ve akademisyenlerin üzerinde yoğunlaştıkları konuların başında örgütün tüm birimlerini etkileyen kurumsal itibar yönetimi gelmektedir. Özellikle 1990'l1 yıllardan sonra gerek akademisyenler gerek uygulamacılar tarafından yapılan itibara ilişkin makale ve kitap 
çalışmalarının marka, pazarlama, örgütsel çalışmalar, stratejik yönetim, iletişim gibi alanlarda hızlı bir gelişme kaydettiği görülmektedir (Martin, Hetrick, 2006:21).

Yapılmış olan akademik çalışmalarda kurumsal itibara ilişkin çok yönlü yaklaşımların olduğu görülmektedir. Ancak kavramın temelinde paydaşların algıları yer almaktadır. Kurumsal itibar, örgütlerin iç/dış çevresindeki kitlenin kurum ile ilgili edindikleri fikir olarak tanımlanmaktadır. Paydaş algısının öneminine değinen bir diğer tanıma göre kurumsal itibar, paydaşların kurumların uzun vadede yüklendiği çevresel, finansal ve sosyal etkilerin sonuçlarını değerlendirdiği kolektif yargıdır (Barnett vd. 2006:28).

Tablo 3'de Chun itibarla ilgili yaklaşımları değerlendirici, izlenimsel ve ilişkisel olmak üzere 3 grupta incelemiş̧tir:

Tablo 3: Kurumsal İtibarın Kavramına İlişkin Yaklaşımlar

\begin{tabular}{lll}
\hline Yaklaşım & Kilit Paydaş Grubu & Kilit Odak Noktası \\
\hline $\begin{array}{l}\text { Değerlendirici } \\
\text { Yaklaşım }\end{array}$ & $\begin{array}{l}\text { Tek Paydaş } \\
\text { (Yatırımcı, yönetici vb.) }\end{array}$ & $\begin{array}{l}\text { Yatırımcı davranışı, CEO'nun düşüncelerine dayalı } \\
\text { sıralama, finansal/stratejik performans ile itibar } \\
\text { bağlantısı vb. }\end{array}$ \\
$\begin{array}{l}\text { İzlenimsel } \\
\text { Yaklaşım }\end{array}$ & $\begin{array}{l}\text { Temel olarak tek paydaş } \\
\text { görüşü }\end{array}$ & $\begin{array}{l}\text { İmaj/Kurumsal Kimlik, itibarın satın alma niyeti ile } \\
\text { bağlantısı, müşterinin gözünde şirket ve satış } \\
\text { personelinin imajı,, itibarın çalışan özdeşleşmeleri ile } \\
\text { bağlantısı vb. }\end{array}$ \\
& $\begin{array}{l}\text { (Müşteri, çalışma, medya } \\
\text { vb.) }\end{array}$ & $\begin{array}{l}\text { Çeşitli paydaşlar, kurumsal itibara ilişkin içsel görüş } \\
\text { (kimlik) ve dıssal görüş (imaj) arasındaki bağlantı vb. }\end{array}$ \\
İlişkisel Yaklaşım & $\begin{array}{l}\text { Özellikle iç ve dış paydaşlar } \\
\text { olmak üzere farklı paydaş } \\
\text { grupların görüşlerinin } \\
\text { karşılaştırılması }\end{array}$ & \\
& & \\
\hline
\end{tabular}

Kaynak: Chun, 2005: 94.

Değerlendirici yaklaşımda; finansal başarıların değerlendirilmesiyle kurumun itibarı belirlenir. Çeşitli sektörel dergilerin yürüttüğü itibar faaliyetleri genellikle değerlendirici yaklaşıma uygun olarak planlanır ve araştırmaların kilit paydaşları; kurumun finansal performansı ile ilgilenen ortaklar, yatırım danışmanları ve CEO'lar (icra kurulu başkanları) olarak kabul edilmektedir. İzlenimsel yaklaşımda ise itibar işletmeye ilişkin genel izlenim olarak kabul edilmektedir. $\mathrm{Bu}$ yaklaşımda, itibarın çalışan özdeşleşmeleri ile bağlantısı, satın alma niyeti ile ilişkisi, medya ile bağlantısı gibi tek paydaş grup üzerinde etkisi incelenmektedir. İzlenimsel yaklaşımdaki araştırmacılar, itibarı tek paydaş algılamalarının birikiminin bir yansıması olarak görme eğilimindedir. İlişkisel yaklaşım ise farklı paydaşların farklı beklentilere sahip olduğunu kabul eden paydaş teorisine dayanmaktadır. Bu yaklaşımda itibar içsel/dışsal görüşlerin eşit yansıması olarak görülmektedir. İlişkisel yaklaşımda, içsel ve dışsal paydaşlara eş güdümlü odaklanılır ve paydaşların algıları arasındaki farklılıklar ve etkileşim üzerinde durulur (Chun, 2005: 93-94).

Örgütlerin giderek finansal göstergelerle ifade edilebilen değerlerin yanında görünmeyen değerlere daha çok önem vermeye başladıkları görülmektedir. İhracat, satış ya da kâr rakamları kurum başarısının somut verileri olarak görülmekle birlikte, bugün bu büyüklüğü ifade eden verilerin yanında toplumun geniş kesimlerinin desteğini alabilme ya da beğenilme gibi değerlerin çok daha önemli hal aldığ 1 ve bir rekabet ölçüsü olarak görülmeye başladığg ifade edilmektedir. En güçlü olmak yerine en beğenilen olmak, paydaşların takdirini kazanmak ve daha önemlisi bunu beğeniyi sürdürebilmek başarının en temel koşulu haline geldiği bilinen bir gerçektir. Bu nedenle 
günümüzde kurumsal itibar yönetimi kurumlar için en önemli değer olarak karşımıza çıkmaktadır (Sarıkaya ve Oruç, 2010: 96).

Olumlu bir kurumsal itibar, paydaşlar için çeşitli yararlar sağlamaktadır. Sürdürülebilir rekabet üstünlüğü sağlamada olumlu itibarın sağladığı yararlar, farklı yazarlarca yapılmış araştırmalar incelenerek Tablo 4'de ifade edildiği şekilde özetlenebilir (Öncel, 2010: 49-50):

Tablo 4: Olumlu Bir İtibarın Yararları

\begin{tabular}{|c|c|}
\hline Müşteriler Açısından & İşgörenler Açısından \\
\hline 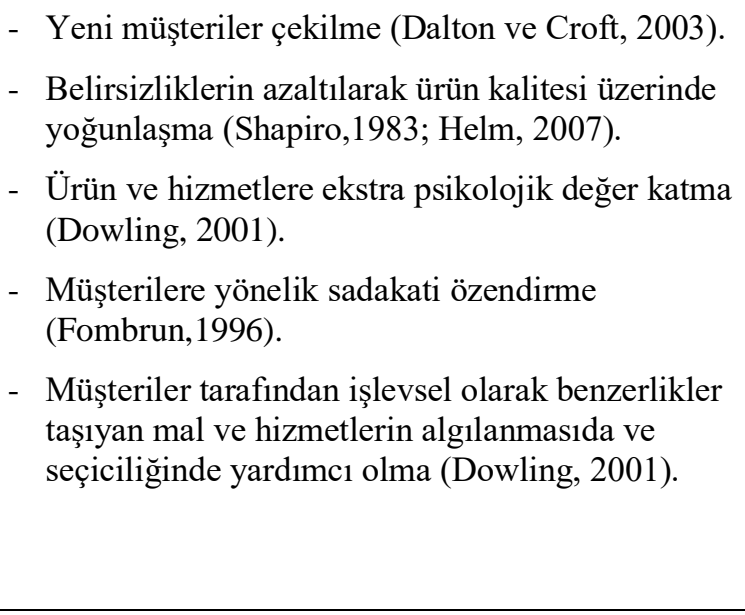 & $\begin{array}{l}\text { - En iyi çalışanları kuruma kazandıracak, çekici } \\
\text { bir çalışma ortamının geliştirilmesine katkı } \\
\text { sağlama (Fombrun,1996; Helm, 2007). } \\
\text { - İşgörenler üzerinde belirsizliklerin azaltılarak } \\
\text { hali hazırda ve gelecekte iş karakteristiği } \\
\text { kazandırma (Cable ve Graham, 2000; Helm, } \\
\text { 2007). } \\
\text { - İşgörenlerin bağlılığını artırma } \\
\text { (Fombrun,1996). } \\
\text { - İş görenlerin memnuniyetini artırma (Dowling, } \\
\text { 2001). } \\
\text { - İyi işgörenleri elde tutma (Dalton ve Croft, } \\
\text { 2003). }\end{array}$ \\
\hline $\begin{array}{l}\text { Çevresel İliş̧kiler Açısından (ortaklıklar, } \\
\text { tedarikçiler, vb.) }\end{array}$ & Yatırıcımlar Açısından \\
\hline 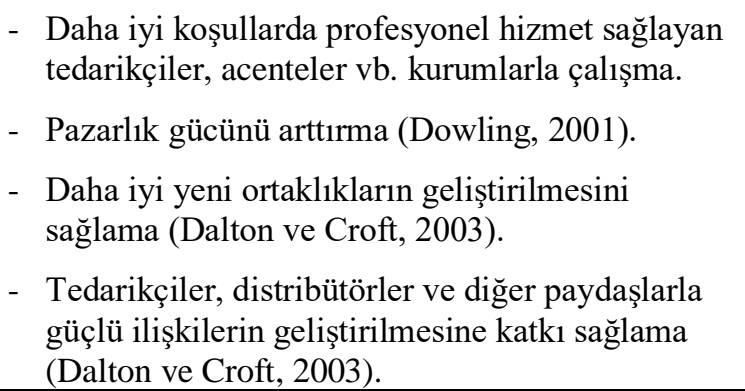 & $\begin{array}{l}\text { - } \quad \text { Yeni yatırımcıları çekme (Helm, 2007). } \\
\text { - } \quad \text { Yatırımcılarla ilişsilerin geliştirilmesine katkı } \\
\text { sağlama (Helm, 2007). } \\
\text { - } \quad \text { Iyi bir itibara sahip olarak algılanan bir işletme } \\
\text { olarak, daha düşük finansal risk ile daha fazla } \\
\text { finansal performans elde etme (Helm, 2007). }\end{array}$ \\
\hline
\end{tabular}

Kaynak: Öncel, 2010: 49-50.

Kurumsal itibar kolektif ya da bireysel yargılardan oluşmaktadır. Bu yargılar gerçek dünyadan gelen bilgilerin algılanmasıyla oluşmaktadır. Dolayısıyla, kurumsal itibarın kurumsal gerçeklikler (kurum kimliği) ve bunların algılanışı (kurumsal imaj) ile ilişkili olduğunu söylemek mümkün olmaktadır (Sadedil, 2011: 4).

\subsubsection{Kurumsal İtibarın Temel Bileşenleri}

Kurumlarda değişen ve gelişen iletişimin stratejik rolüne paralel olarak halkla ilişkiler disiplini de farklılaşmaktadır. Bu bağlamda işletmelerin finansal sorumluluklarına paralel olarak üstlendikleri kurumsal sosyal sorumluluk, kuruluşa duyulan güven, paydaşlarla ilișkiler ve hizmetin kalitesi gibi bileşenlerle ilişkilendirilen itibar, halka ilişkilerin yeni rekabet koşulları içinde kurumsal becerilerinin kaynağını oluşturmaktadır. Çünkü itibar, işletmelerde ne yapıldığına ve nasıl yapıldığına odaklanan ve paydaşların tecrübelerine bağlı olarak algıya dayanan çok yönlü bir bileşendir (Yirmibeş, 2010: 25). 
Kurumsal itibarın temel bileşenleri, çalışan ve yönetim kalitesi, ürün ve hizmetler, liderlik ve vizyon, çalışma Ortamı, duygusal çekicilik ve finansal performans kavramlarından oluşmaktadır. $\mathrm{Bu}$ altı bileşene göre, sosyal paydaşların, birçok sektörde kurumlarla ilgili algılamaları ölçümlenmektedir. Shandwick International adlı halkla ilişkiler danışmanlığg şirketi ve Harris Interactive Araştırma Şirketi ortaklı̆̆ında ABD'de yapılan odak grubu (focus group) çalışmalarında, Amerikalı insanlara kurumlarda nelerden hoşlandıkları ve saygı duydukları, nelerden hoşlanmadıkları ve saygı duymadıkları sorulup, ne hissettikleri öğrenilmeye çalışılmıştır. Bunun sonucunda, yukarıda sıralanan 6 bileşenin altında bulunan 20 nitelik ortaya çıkmıştır. (Babal, 2010: 42).

Yönetim Kalitesi: Herhangi bir kurumun nitelikli bir yönetim ve kaliteli çalışanlara sahip olması, onu rakiplerinden bir adım öne taşımaktadır. Özellikle yönetim tarafından stratejik kararların alınması ve bu alınan kararların çalışanlarca uygulanması aşamalarında nitelikli iş̧ gücünün önemi bir kat daha artmaktadır. Kurumsal itibarı yüksek olan bir kurumun, en iyi üniversitelerden mezun olan nitelikli işgücünü doğrudan kendisine çekeceği düşünüldüğünde, kurumsal itibar ve nitelikli eleman istihdamı kavramlarının karşılıklı olarak birbirlerini destekledikleri sonucuna varılabilir. Paydaşların kuruluşa karşı olan güvenini artıran başlıca unsur, yönetim ve çalışanlarının kalitesidir. Bu, kamuoyuna bir anlamda kullandıkları ürün ve hizmetlere dair bilgilendirilme ihtiyaçları doğrultusunda kaynak güvenilirliği oluşturmaktadır (Altıntaş, 2005: 25).

Dünyanın önde gelen firmalarının üst kademe yöneticilerinin, itibarlarını olumlu yönde etkilemek için GRC (Governance, Risk \& Complience) olarak tanımlanan iyi kurumsal yönetim, risk yönetimi ve uygunluk denetimi uyguladıkları ve bunun itibarlarını olumlu yönde arttırdığı yapılan araştırmalar sonucunda ortaya çıkmaktadır (Kadıbeşegil, 2007: 77).

Liderlik: Vizyon, bir firmanın ne olabileceğine dair gelecekle ilgili bir görüş, o işletmenin gelecekteki durumu ve başarısı ile ilgili bir hedef, işletmenin potansiyel geleceğini gösteren bir fotoğraf olarak tanımlanabilir. Vizyon oluşturma, kurumun gelecekte kendi varlığının nasıl görüneceği, nasıl davranacağı ve hangi tercihlere sahip olacağına dair hayali bir resim yaratmak olarak da tanımlanabilir. Diğger bir göre ise; vizyon, yöneticinin kendine özgü, gelecekte yapılması düşünülen tüm faaliyetler ile alternatifler topluluğunun algılanması, tanımlanması, değerlendirilmesi, açıklanması ve paylaşılmasıyla ilgili zihinsel süreç ve gayretlerdir. Liderlerin astları ile görüşmesi, fikirlerini açıklaması, paylaşması ve onları ikna ederek motive etmesi vizyon oluşturmada önem arz eden bir husustur. Vizyonu olan birçok firma, bunu bir vizyon bildirisi ile açıklamaktadır. Bir vizyon ifadesi, çalışanların, kurum itibarını olumlu bir şekilde algılamasında hayati bir rol oynar. Örgütün içerisinde hazırlanan vizyon ifadeleri, dış paydaşlarla sağlanan iletişimde de kullanılır ve içerdiği güvenilir bilgiye bağlı olarak oluşmaktadır. Aynı zamanda insanlar ortaya çıkan bilgiye göre, bunu kurumun itibarını şekillendirmede kullanmaktadırlar (Yirmibeş, 2010:29).

İtibarın yüzde ellisi liderin omuzlarındadır. Yapılan araştırmalar da gösteriyor ki bir işletmenin, çevresinde olumlu ya da olumsuz şekilde tanınıyor olması liderin konuyla ilgili performansından kaynaklandığı düşünülmektedir. $\mathrm{Bu}$ durumda işletmelerde lider konumunda olanların itibar yönetiminin başarı faktöründe kritik bir varlığı olduğu söylenebilir. Nereye nasıl gidileceğine geminin kaptanı olan lider o karar verdiğinden itibarın ağır yükü de doğrudan liderin omuzlarındadır (Kadıbeşegil, 2005: 12).

Buradan hareketle lider grupların ve organizasyonların amaçlarına ulaşmalarını sağlamak üzere gruptaki ve organizasyonlardaki üyeleri etkileyen kişiler olarak tanımlanabilir. Bir başka tanıma göre lider diğer kişilerin faaliyetlerini etkilemekte kullanılan güç şekli olarak tanımlanmaktadır (Arıkan, 2001: 285). 
Liderin önderliğinde gelişen vizyon ifadeleri, kurumun değerleriyle ve yönetim felsefesiyle olan iletişiminde ve bunu şekillendirmede yardımcı rol oynamaktadır. Aynı zamanda çalışan değeri, sosyal sorumluluk, kurumsal performans gibi anahtar performans ölçütlerini belirler. $\mathrm{Bu}$ şekilde de kurumsal itibar oluşumuna katkıda bulunulmuş olur (Dowling, 2001: 83).

Ürün: İşletmeler tarafindan üretilen ürün ve hizmetler ile dış paydaşlar ile ilişki kurulur. Firmanın varlığını devam ettirebilmesi için bu ilişkinin olumlu ve sürekli olması gerekmektedir. Dış paydaşların kaliteli ürün ve hizmetlerle karşı karşıya kalması işletmenin tercih edilebilirliğini arttıracağı kaçınılmaz bir gerçektir. Alınan hizmet ve ürün kaliteli olarak algılandığında dış paydaşların firmaya bakış açıları da olumlu yönde değişmekte ve işletmenin ürün ve hizmetleri ile ilgili olumlu deneyimler işletmenin kurumsal itibarını dış paydaşların gözünde arttırıcı bir etki sağlamaktadır. Aynı şekilde tüketicilerin işletmenin ürün ve hizmetleri ile ilgili dış paydaşların olumsuz deneyimleri de işletmenin dış paydaşların nazarında kurumsal itibarın olumsuz yönde etkilenmesine neden olacağı değerlendirilmektedir (İcil, 2008: 23).

Çalışma Ortamı: Kurumsal bir işletmede özellikle stratejik kararların alınması ve bu alınan kararların uygulanması aşamalarında nitelikli iş gücü bulunması gerekmektedir. Kurumsal itibarı yüksek olan bir işletmenin, nitelikli işgücünü doğrudan kendisine bünyesine çekeceği düşünüldüğünde, kurumsal itibar ve nitelikli işgüçü istihdamı kavramlarının birbirlerini desteklediği sonucuna varılmaktadır (Üçok, 2008: 43). Dolayısıyla paydaşlardan biri olan çalışanlar açısından çalışma şartlarının ve ortamının iyi olması, iç paydaşların memnuniyeti noktasında oldukça önemli bir faktördür. Bu sebeple, kuruluş yönetimi tarafindan gerekli uygun koşulların hazırlanması, çalışanların kendilerini değerli ve öncelikli hissetmelerini sağlaması bakımından önemlidir. Bu olumlu süreç, çalışanların, işletmenin amaçları doğrultusunda çalışmalarına ve motivasyonlarının artmasına sebep olacağı düşünülmektedir. Çalışanların sosyal ve mesleki yönden adil bir biçimde desteklenmeleri ve kendilerini kişisel olarak geliştirebilecekleri güvene dayalı bir işbirliğinin hakim olduğu bir çalışma ortamının oluşturulması çalışanların başarısını ve kurumsal itibarı arttıracağı düşünülmektedir (Üçok, 2008:44).

Finansal: İşletmeler için gerçek anlamda en önemli sermayeleri itibar olarak algılansa bile finansal yapı ile itibar arasında güçlü bir bağ olduğu unutulmaması gereken bir durumdur. Kurumuna bağlı çalışan profiline sahip işletmelerin performansının ve finansal getirilerinin artacağı konusunda çalışmalar bulunmasına rağmen, örgütlerin finansal durumunun güçlü olmasının örgütsel bağlılığı hangi yönde etkileyeceğine dair kuramsal ya da uygulamalı çalışmalara rastlanamamıştır. İşletmenin karlılığının, örgütsel bağlılık arasında direkt bir ilişki bulunmamasına karşın, özelikle az gelişmiş toplumlarda ekonomik belirsizliğin, buna bağlı olarak riskin fazla olması, güçlü finansal yapıya sahip kurumların daha güvenilir ve güçlü olduğu varsayımının çalışanlar tarafından yapılmasına neden olmaktadır. İş güvencesi açısından bakıldığında, finansal yapısı güçlü işletmelerin çalışanlara yapılacak ödemeler, iş güvencesi gibi konularda daha güvenilir olduğu dolayısıyla çalışanların bu tür işletmelere bağlllıklarının yüksek olacağı varsayımı yapilabilir (Erhan, 2013: 33).

Duygusal Çekicilik:İtibar katsayısının temel bileşenlerinden biri olarak ifade edilen duygusal çekicilik, kurum ile ilgili pozitif düşüncede olma, güvenilen, saygı duyulan beğenme ile ilgili algısal ifadeler olarak kabul edilmektedir ( Öncel, 2010:77).

Örgütlerin itibar yönetimi süreçlerinde, duygusal çekim kabiliyetlerini arttırabilmeleri için ilk olarak sahibi oldukları duyguları açık bir ifadeyle tanımlamaları gereklidir. Kurumsal itibarlarını arttırmayı hedefleyen işletmeler, iç ve dış paydaşlarına yönelik olarak örgütel duygularını tanımlayarak, yönetmelidirler. Kurumsal itibar yönetim sürecinde örgütsel duyguların tanımlanarak, işletme personelinin duyguya, sezgilere, düşüncelere sahip birey olduklarını fark etmekte, bu doğrultuda örgütlerin duygusal zekâlarının gelişimine katkıda bulunulduğu düşünülmektedir. Örgütsel çerçevede sahip olunan duyguların tanımlanması ile birlikte, duygusal 
itibarın gelişim sürecinin hedef kitlenin yüreğine seslenme ilkesine katkıda bulunulmakta, bu bağlamda hedef kitlelerde örgüte ve örgüt kültürüne karşı bir örgütsel bağl1lık oluşturulabilmekte, oluşturulan bu örgütsel bağll1ık sürekli olarak düzenli bir şekilde geliştirilebilmektedir (Köker, 2010:159).

\subsubsection{Kurumsal İtibar Yönetimi}

Kurum misyonu, vizyon, kurumsal hedefler, kurumsal davranışlar vb. Öğeler ile logo, renk vb. kurumsal dizayn unsurları kuruluşun kurumsal kimliğini oluşturan temel taşlardır. Kurumsal imaj ise, başta tüketiciler olmak üzere hedef kitlelerin zihninde kuruluşla ilgili olarak oluşan görüntülere verilen addır. Kurumsal itibar yönetimi ise, bünyesinde hem kurumsal imajı ve hem de kurumsal kimlik unsurlarını barındıran ve hedef kitle üzerinde kurumla ilgili olumlu bir etki yaratmayı amaçlayan bir iletişim süreci olarak tanımlanmaktadır (Kadıbeşgil, 2001: 41). Kurum içerisinde itibar yönetimi süreci Şekil 1'de görüldüğü gibidir:

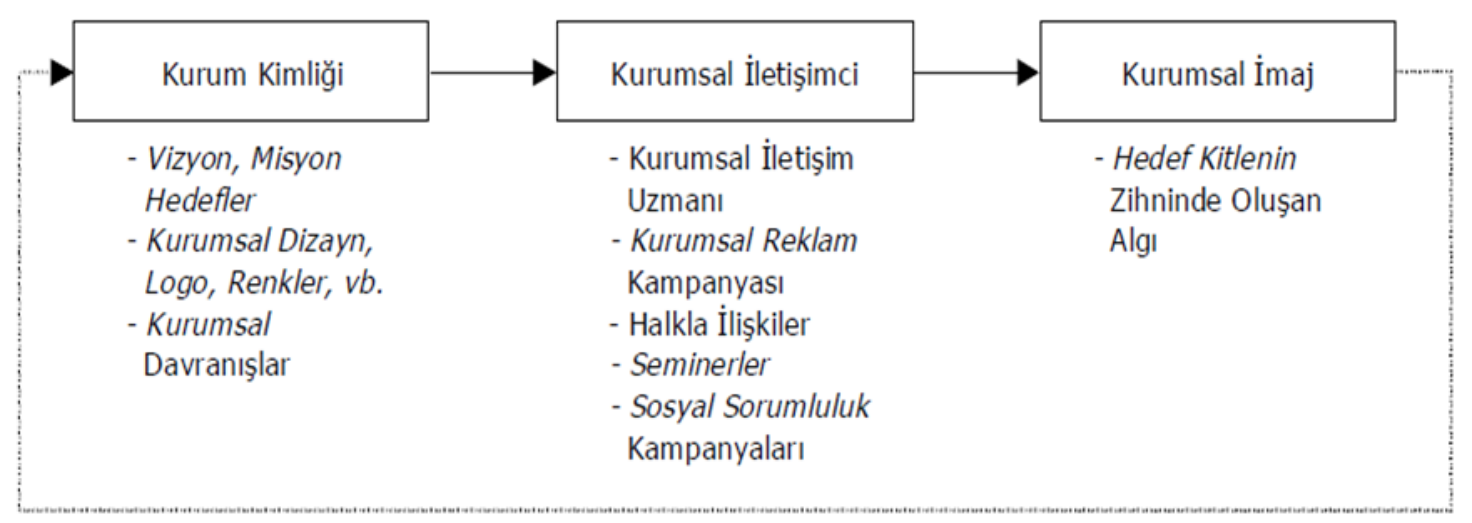

Şekil 1: Kurum İçerisinde İtibar Yönetimi Süreci

Kaynak: Kadıbeşgil, 2001:41.

$\mathrm{Bu}$ iletişim sürecinde kuruluş tarafindan gönderilen iletiler doğrudan kurum kimliğinden beslenerek şekillenmektedir. Bir başka deyişle, itibar yönetimi sürecinde hedef kitleye iletilen mesajlar, işletmenin kurumsal kimliğine ilişkin unsurlardır. Burada özellikle kurumun misyonu, vizyonu ve kurumsal davranışlar kuruluşun itibarına olumlu katkıda bulunabilecek temel faktörlerdir. Kurumsal dizayn ise, kurumun diğer kuruluşlardan ayırt edilebilmesini sağlar, tüketicilerde kurum ile ilgili farkındalık yaratır ve işletmeye aşinalık sağlanmasına neden olur. (Altıntaş, 2005:23).

İtibar güven odaklıdır. Kurumsal itibar bir sürecin sonunda oluşmaktadır. Deyim yerindeyse iğneyle kuyu kazarak elde edilen kazanımların bir sonucudur. Fakat oluşturulmuş itibarı yerle bir etmek tıpkı domino etkisinde olduğu gibi çabuk ve hızlı gerçekleşir. Örneğin, bu günlerin popüler tartışma konusu olan Volkswagen araçlarında ortaya çıkan emisyon gazı skandalı, geçmişi uzunca yıllara dayanan güçlü bir markanın itibarına büyük bir zarar vermiş, itibarı sarsılan kurumun hisse değerleri olağanüstü düşüşgöstermiş ve bu yaşanılan skandal belki de çok uzun yıllar boyunca onarılamayacak kadar büyük zararların ortaya çıkmasına zemin oluşturmuştur. (Güler vd., 2015:3)

Kurumsal itibar yönetimine olan ilginin artmasının en önemli sebeblerinden biri, itibar yönetiminin özellikle 1990'lı yıllarda oldukça başarı kazanan kriz yönetimi uygulamalarının 
önemli bir unsuru olmasından kaynaklanmaktadır. Küreselleşmenin hız kazandığı bir piyasada kuruluşlar artık sadece ulusal etkilere maruz kalmamakta, bunun yanı sıra işletmelerin faaliyetleri küresel boyutta da yankı bulmaktadır. Özellikle birden fazla coğrafi bölgede faaliyet gösteren çok uluslu kuruluşlar için kurumsal itibar, şirketin uzun vadeli performans değerlerini etkileyen ve hatta belirleyen temel bir faktör haline geldiği söylenebilir. (Altıntaş, 2005:23).

\subsubsection{Kurumsal İtibar}

Tespit edilemeyen performans geliştirilemez. $\mathrm{Bu}$ nedenle itibarı iyi bir şekilde yönetebilmek için düzenli olarak itibarın ölçülmesi gerekmektedir. İyi bir itibar yönetimi sistemini oluşturabilmek için paydaşların tespit edilmesi ve temsilinin oluşturulması, ölçülecek itibar boyutlarının saptanması, ölçümlerinin yapılarak belli zaman dilimi içinde varılmak istenen hedeflerin tespiti gerekmektedir. Ama kuruluşlar, ölçüm konusunda şüpheli bakmaktadırlar. Sadece bazı kurum ve kuruluşlar kendi itibarlarını ölçme ve izleme noktasında spesifik misaller sunmaktadırlar. Bununla birlikte işletmeler bir ya da birden fazla sahada medya ölçüm tekniklerini kullanmaktadırlar. Bazı işletmelerde tüketici fikirlerini ölçmek için pazar araştırması araçlarını kullanmaktadırlar (Argüden, 2003: 12).

Literatürde ölçme teknikleri incelendiğinde birçok yöntem görülmektedir. Bu çokluluk arasında kurumsal itibar ölçümü insanların örgütle ilgili sosyal beklentileri, insanların kuruma atfettiği farklı kişilik özellikleri, insanların kuruma güvenme ya da güvenmeme düzeyleri altında üç ana içeriğe dayanmaktadır. İlk gruptaki ölçüme Fortune Dergisi "En Beğenilen Şirketler" çalışması, ikinci gruptaki ölçüme Davies tarafindan oluşturulan "Kurumsal Kişilik Metaforu", üçüncü gruptaki ölçeğe ise Newell ve Goldsmith tarafindan oluşturulan "Kurumsal Güvenilirlik Skalas1" misal olarak verilebilmektedir (Bozkurt, 2011: 50).

Değişik oranlama metodlarına karşı içsel önyargıları ortadan kaldırabilmek amacıyla endüstrinin ve çeşitli kitlelerin işletmeye karşı olan düşüncelerini ölçmek üzere 1998 y1lında Harris Interactive tarafindan Reputation Institute Reputation Quotient/RQ ismi altında bir sistem tasarlanmıştır. $\mathrm{Bu}$ modelin tasarlanmasında insanlara örgüt isimleri, o kuruluşlara saygı duyup/duymadıkları, onlardan hoşlanıp/ hoşlanmadıkları soru olarak sorulmuştur. Bu değişik endüstrilerdeki ve gruplardaki verilerden yapılan çalışmalar neticesinde bireylerin kuruluşlar hakkındaki görüşlerinin davranış şekli ve 6 boyutta olduğu ortaya tespit edilmiştir. Bu altı boyut aşağıdaki sıralanmıştır (Fombrun ve Boss, 2001:1):

i. Duygusal Cazibe: Kuruluştan ne kadar hoşlanıldığı ve kuruluşa ne kadar sayg1 duyulduğu ile ilgili bir husustur.

ii. Ürünler ve Hizmetler: Değer ve yenilik algısı, kalitesi ile kuruluşun ürünlerine ve hizmetlerine duyulan güven ile ilgilidir.

iii. Finansal Performans: Kuruluşun karlılık, risk/ beklenti düşüncesi ile ilgilidir.

iv. Vizyon ve Liderlik: Kuruluşun net bir vizyon ve güçlü bir liderlik göstermesi ile ilgilidir.

v. Çalışma Ortamı: Kuruluşun iyi yönetildiğine dair duyulan algı ile çalışanlar için çalışma kalitesinin sağlanması ile ilgilidir.

vi. Sosyal Sorumluluk: Kurumun topluluklarla, çalışanları ile ve çevreyle olan ilgilerinde iyi bir vatandaş olarak algılanmasıyla ilgilidir.

Fortune Dergisi kriterleri 1984 y1lından bu yana uygulanmaktadır. Fortune çalış1lacak en iyi 100 kuruluş diye de bir liste oluşturmuştur. 2000 yllında en iyi 100'ü seçebilmek için 23 aday oldukça sıkı bir analizden geçirilmiş, çalışanlarından rastgele seçilmiş bir grupla araştırma yapılmıştır. O yıl yaklaşık 36.000 çalışan, yönetime duyulan güveni işten ve işletmeden duyulan 
gururu ve yoldaşlığ değerlendiren bir anket formu doldurmuştur. Yaklaşık 14.000 kişi ayrıca firmaları hakkında yorumlar yazmıştır. Araştırma ve yorumlar puanlamanın üçte ikisini oluşturmuştur. Puanların geri kalan kısmı, işletmelerin felsefe ve uygulamalarına ilişkin, kendi açıklamalarına ve çalışan el kitapları, şirket bültenleri ve videoları gibi ek materyallere bakılarak verilmiştir (Gezmen, 2014:49).

\subsubsection{Kurumsal İtibar İle İlgili Yapılan Çalışmalar}

İtibar ve kurumsal itibara yönelik olarak literatür incelendiğinde, bu alana yönelik çalışmaların hem yurt içinde hem de yurt dışında 1990'lı yıllardan sonra artmaya başladığ 1 görülmektedir. Dünyada kurumsal itibara ilişkin çalışmalar incelendiğinde başlıca bir takım çalışmalar olduğu görülmektedir. Bu konuda yazılmış ilk kitap, Mayıs 1993 yılında piyasaya çıkan D.B. Bromley'e ait Reputation, Image and Impression isimli çalışmadır. Bromley bu çalışmasında kurumsal itibar, kimlik, imaj ve marka gibi kavramları inceledikten sonra kurumsal itibara yönelik bir model geliştirmiştir (Karaköse, 2006: 173).

Kurumsal itibarın ölçülmesine yönelik en önemli çalışmalardan birisi Reputation Institute'nun kurucusu ve müdürü olan ve bu alanda pek çok makale ve kitaba imza atan Charles Fombrun'a ait Reputation Quotient yani itibar katsayısı ölçeğidir. Bu ölçekte, paydaşların, kurumsal itibarı duygusal cazibe, ürün ve hizmetler, finansal performans, vizyon ve liderlik, çalışma ortamı ve sosyal sorumluluk olmak üzere 6 farklı boyutta, 20 ifade ile nasıl gördükleri tespit edilmeye çalışılmaktadır. İngiltere'de ve Amerika Birleşik Devletleri'nde çeşitli üniversitelerde yönetim, kriz yönetimi ve stratejik yönetim konularında dersler veren Judy Larkin'e ait Strategic Reputation Risk Management isimli kitabın 2003 yılında yayımlanmasıyla birlikte ilk olarak Kurumsal İtibar Yönetimi stratejik yönetim ve stratejik iletisim yönetimi çerçevesi içinde ele alınmaya başlanmıştır (Tüysüzoğulları, 2010:23-24).

Kurumsal itibar yönetimi, doğasında çok fazla parametreyi barındırmakta, Türkiye'de birkaç kuruluş dışında uygulamada yer verilmeyen, içeriği ve boyutları kurumlar tarafindan tam olarak anlaşılmamış bir konudur. Mevcut durumda danışmanlık firmaları tarafından yürütülen çeşitli çalışmalar dışında uygulamada çok fazla yer bulmadığı gibi, akademik açıdan konu ile ilgili çalışmalar sınırlı düzeyde kaldığı görülmektedir (Öncel, 2010: 90).

Kurumsal itibar yönetimi konusunda ilk olarak 1999 yılında iş ve ekonomi dergisi Capital'in öncülüğünde gerçekleştirilen araştırma ile Türkiye'de en beğenilen şirketler belirlenmiştir. Son yıllarda bu araştırmalar düzenli olarak aynı dergi tarafından yürütülmekte ve iş dünyasında büyük bir ilgiyle sonucu beklenmektedir. $\mathrm{Bu}$ araştırma, iş dünyasında özellikle yöneticiler açısından, aynı sektör içerisinde yer alan farklı kuruluşları değerlendirilmeleri ile şekillenmektedir. Kurumsal itibar yönetimi kavramını akademik bakış açısı ile ilk olarak ele alan çalışmalardan birisi de Argüden (2003) tarafından Ar-Ge danışmanlık yayını olarak yapılmış, ardından Kadıbeşegil (2006) tarafından İtibar Yönetimi adı altında bir kitap olarak yayınlanmıştır. Karaköse tarafindan yayımlanan "Kurumların DNA'sı İtibar ve Yönetimi" , Er tarafından "Sanal Ortamda İtibar Yönetimi”" adlı çalışmalar yürütülen tezlerin kitap haline getirilmesi ile literatüre kazandırılmıştır. Erkan Altıntaş (2005), "İtibar yönetimini ve Anadolu Üniversitesi İ.İ.B.F.Örneği" adlı yükssek lisans çalışması ile yaptığı araştırmada, Anadolu üniversitesinde çalışan akademik personel, idari personel ve öğrenciler perspektifinde yürüttüğü araştırmasında, söz konusu paydaşlar arasında algılamalarında bir farklılık olup olmadığını anket çalışması ile kurum düzeyinde gerçekleştirmiştir. İtibar Yönetimi ile ilgili ilk doktora çalışması 2006 y1lında Turgut Karaköse tarafından yapılmıştır. Karaköse, "Eğitim Örgütlerindeki İç ve Dış Paydaşların Kurumsal itibara ilişkin Algılamaları" adlı tez çalışması ile Altıntaş'ın çalışması ile paralel kriterler kullanılarak, ilköğretim düzeyinde hedef kitlenin kurumsal itibara ilişkin algılamaları arasında anlamlı bir farklılık olup olmadığını araştırmıştır (Öncel, 2010: 90). 
Kurumsal itibar yönetimi konusunda bir başka çalışma, Türkiye'den en iyi on üniversitenin belirlenmesi amacıyla Kocaeli üniversitesi araştırma fonu tarafindan desteklenen bir araştırma ile yetmiş dört üniversitenin rektörlerine gönderilerek, en iyi on üniversite belirlenmeye çalışılmıştır. 2008 yılında 16.'sı düzenlenen "Yönetim ve Organizasyon" Can Saruhan,ve Dilek Üçok, “ Kurumsal İtibar Yönetimi ve Reptrak İtibar Endeksi Yardımıyla Bir Araştırma", adlı bildirisinde Marmara Üniversitesi Sosyal Bilimler Enstitüsünde eğitim öğretim faaliyetleri yürüten akademik personel ile öğrenciler üzerinde yaptığı araştırmada Harris-Fombrun Katsayısı kullanılarak, kurumsal itibarı daha spesifik bir boyutta incelenmiştir (Öncel, 2010:91).

\subsection{Halkla İlişkilerin Kurumsal İtibar Üzerine Etkisi}

Halkla ilişkiler ile kurumsal itibar arasındaki ilişki ile ilgili iki farklı yaklaşım bulunmaktadır. Bu yaklaşımlardan birincisi iletişim yönlü yaklaşım olup kurumsal itibarın birtakım iletişim çalışmaları neticesinde elde edilebileceğini söylerken, ikincisi kurumsal paydaşların ve davranışların kuruluşla olan doğrudan kişisel deneyimlerinin kurumsal itibarın yaratılması ve devam ettirilebilmesinde iletişimden daha önemli olduğunu ifade eden davranış yönlü yaklaşımdır (Akbulut 2011: 142).

Halkla ilişkilere etkin ve başarılı bir iletişim sağlamada araçsal bir işlev yükleyen ilk yaklaşım, halkla ilişkileri kurumsal itibar yönetim sürecinde bir imaj yaratma unsuru olarak görmekte ve bu süreçte halkla ilişkilerin yeni ürün ve hizmetler hususunda tüketicileri eğitme, medyada yer alan haberler aracılığıyla üçüncü tarafların desteğini sağlama, algı ve tutumları değiştirme ve çeşitli araştırmalar aracılığıyla mevcut veya olası sorunlar hakkında farkındalığı artırma gibi roller üstlendiği ileri sürülmektedir. İkinci yaklaşım ise halkla ilişkilere daha stratejik bir rol yüklemektedir. Halkla ilişskilerin kurumsal itibar yönetim sürecindeki işlevine ilişkin bu yaklaşım farklılıklarının aslında halkla ilişkilerin temel işlevine yönelik varsayımlardan kaynaklandığı söylenmektedir. Buna göre iletişim yönlü yaklaşım, halkla ilişkilerin temel görevinin paydaşların işletmeye ilişkin algılarını etkileme olduğunu kabul etmekte ve bu sebeple daha fazla tanıtım faaliyetleri, medya ile ilişkiler ve medyanın paydaşlar üzerindeki etkileri üzerinde odaklanmaktadır. $\mathrm{Bu}$ bağlamda iletişim yönlü yaklaşıma göre halkla ilişkiler, paydaşların hafizalarında kuruluşun istediği şekilde davranmayla neticelenecek bir izlenim yaratacak taktiksel bir fonksiyondan öteye gitmeyeceği ifade edilmektedir. İkinci yaklaşım olan davranış yönlü yaklaşım ise paydaşların kuruluşla ilgili değerlendirmelerinin kurumsal davranışlar sonucunda şekillendiğini kabul etmekte ve bu bağlamda halkla ilişkilerin kurumsal davranışların yönetilmesine yardım etmek üzere kurumdaki karar alma sürecine katılımını ve bu yönüyle stratejik bir rol üstlenmesi gerektiği ileri sürülmektedir. Söz konusu stratejik rol ise bir yandan paydaşların düşünce ve görüşlerinin karar alma sürecinde temsil edilmesini, diğer taraftan işletme ile paydaşlar arasında bir iletişimin geliştirilmesini kapsamaktadır. Kuruluş ile paydaşları arasında iki yönlü ve simetrik iletişimin önemini ifade eden bu yaklaşım, düşünülenin aksine medya ile iyi ilişkilerin kurulmasını ve tanıtım faaliyetlerinin gerçekleştirilmesini önceleyen iletişim yönlü yaklaşım ile taban tabana zıt bir görüş ileri sürmediği görülmektedir. Tersine bu türden iletişim çabalarına simetrik bir bakış açısıyla yaklaşılması ve böylece kurumsal mesajların sadece kuruluşun istediklerini değil aynı zamanda paydaşların alg1 ve beklentilerini de yansıtması gerektiğini öngörmektedir. Kurumsal itibar ile halkla ilişkiler arasındaki ilişki kurumsal itibarın öncülleri bağlamında ele alındığında halkla ilişkilerin kurumsal itibar yönetim sürecindeki rolüne ilişkin yaklaşımlardan iletişim yönlü yaklaşımın, kurumsal itibar öncüllerinden "ün"e karşıllk geldiği ve bu yönüyle kurumsal imaja ağırlık verdiği, buna karşılık davranış yönlü yaklaşımın ise algılanan "kalite" boyutunu temsil ettiği ve kurumsal kimlik üzerinde yoğunlaştığı düşünülmektedir (Akbulut 2011:143-144) 


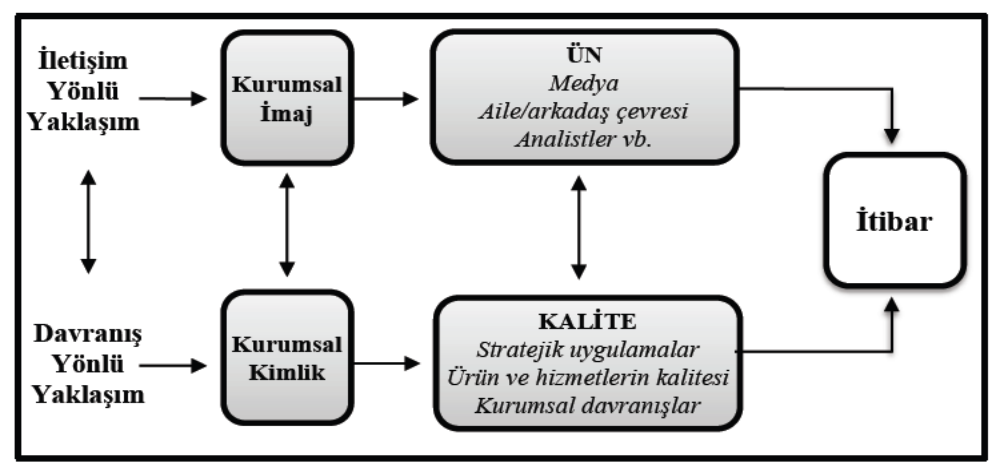

Şekil 2: Kurumsal İtibarın Öncülleri ve İlgili Yaklaşımlar

Kaynak: Akbulut, 2011:144.

Kurumsal itibarın iki farklı öncülü olan ün ve kalite öncülü ve bu öncüllere karş1lık gelen yaklaşımlar, halkla ilişkilerin de farklı roller üstlenmesini beraberinde getirmektedir. Bu bağlamda halkla ilişkiler ya doğru paydaşlara doğru mesaj verme görevini yerine getirerek kurumun bilinirliğini/ününü artırır ya da stratejik kararların alınmasında kuruluşun yönetimine tavsiyede bulunarak işletmenin stratejik olarak iyi bir noktada olmasını sağlar (Akbulut 2011: 146).

Halkla ilişkiler, kurumsal mesajları destekleyen ve geliştiren, böylece itibari bir değer yaratan bütünleşik pazarlama unsurları arasında bir eşik bekçisi veya bir koordinatör işlevi görmektedir. Kurumsal İtibarın elde edilmesi, sürdürülmesi ve korunmasında halkla ilişkilere yüklenen bu fonksiyon, medyadaki olumlu mesajların kuruluş hakkında olumlu, olumsuz mesajların ise olumsuz izlenimlere yol açacağını öngören iletişim yönlü yaklaşımın bir yansımasıdır. Dolayısıyla bu yaklaşıma göre halkla ilişkilerin temel işlevi stratejik mesaj yaratmadır. Başka bir deyişle halkla ilişkiler sembolik mesajlar üretip bunları ilgili paydaşlara ileterek kurumun olumlu bir itibar elde etmesine katkıda bulunmaktadır (Dalton ve Croft, 2003:127).

Halkla ilişkilere yüklenen diğer bir fonksiyon ise stratejik karar alma sürecinde işletme yönetimine tavsiyelerde bulunmaktır. Davranış yönlü yaklaşıma karşılık gelen bu bakış açısına göre bir kuruluş sadece iletişim çabaları sonucunda olumlu bir itibar elde edemeyeceğinden dolayı halkla ilişkiler, stratejik planlama ve yönetimde kurum itibarının denetleyicisi olarak bir gözetimci rolü üstlenmesi gerekmektedir. Bu gözetimcilik görevi ise halkla ilişkilerin stratejik paydaşları belirleyen, bu paydaşların kuruluştan beklentilerini ve kuruluş hakkındaki görüşlerini araştıran, kurum bünyesindeki karar alıcılarına elde ettiği bu bilgileri sunan ve iletişim süreçlerini yöneterek bu stratejik paydaşlarla kaliteli ve uzun dönemli ilişkiler inşa eden bir yönetim fonksiyonu olarak kabul edilmesiyle mümkün olabilir. Çünkü işletmenin başarısı dolayısıyla olumlu itibar paydaşların çıkar ve beklentilerinin karşılanmasına bağlı olduğu düşünülmektedir. Bu nedenle kurumsal iletişim sadece kurum ile paydaşları arasındaki sorunların çözümünü kolaylaştıran bir araç olduğu söylenebilir. Dolayısıyla halkla ilişkilerin kurumsal itibar yönetim sürecinde aktif bir şekilde işlev görmesi için sadece bir araç görevi üstlenen sembolik bir iletişim buna bağlı olarak sembolik bir itibar yaratma fonksiyonu olarak değil, aynı zamanda stratejik yönetim ve planlama sürecine katılarak karar alma süreçlerinde yönetime stratejik tavsiyelerde bulunan bir unsur olarak kabul edilmesi gerekmektedir (Hutton vd., 2001: 257).

Kurumsal itibarın halkla ilişkilerin aracılığı olsun ya da olmasın ortaya çıkabileceği, bu nedenle halkla ilişkilere "itibar bekçisi" gibi bir işlev yüklemenin başarıda olduğu gibi başarısızlık durumunda da halkla ilişkileri sorumlu kılma gibi bir risk taşıdığından hareketle kurumsal itibar 
yönetim sürecinde halkla ilişkilere gereğinden fazla bir işlev yüklenmemesi gerektiği ileri sürülmektedir. Ayrıca halkla ilişkilerin medya ile kurmuş olduğu ilişki biçimi de halkla ilişkileri itibar elde etmede merkezi bir konuma oturtmayı tartışmalı kılmaktadır. Çünkü halkla ilişkiler, kuruluş ile ilgili bir bilgiyi paydaşlarına iletmek üzere medyayı kullanmaktadır. Fakat bu türden bir iletişim programının başarısı, ilgili paydaşların söz konusu medyanın tarafsızlığına ilişkin düşüncelerine bağlı olduğu öngörülmektedir. Halkla ilişkiler ve medyanın birbirlerini beslemesi şeklinde oluşan bu medya ile ilişki biçimi, halkla ilişkiler mesajlarının editoryal içerik olarak medyada görünmesine olanak tanımaktadır. Ancak gittikçe daha da sofistike olan paydaşlar bunun nasıl yapıldığını bilirler ve hem halkla ilişkilere hem de medyaya karşı duydukları güven duygularının zarar göreceği kaçınılmaz bir durumdur. Sonuç olarak kuruluşa karşı olan güven duygusu azalır. Tüm bu nedenlerden dolayı olumlu bir itibarın sadece iletişim faaliyetleri veya halkla ilişkiler fonksiyonu aracılığıyla elde edileceği gibi bir yaklaşım, yürütülen faaliyetlerin başarısızlıkla sonuçlanmasına yol açacağı öngörülmektedir. Bu bağlamda en doğru yaklaşımın, olumlu itibarın hem iletişim faaliyetleri hem de kurumsal davranışlar sonucunda elde edileceğinin, dolayısıyla halkla ilişkilerin yalnız ve yalnız stratejik mesaj yaratma veya sadece yönetime tavsiyelerde bulunma değil her iki rolü de yürütecek bir fonksiyon olarak kabul edilmesi olduğu ileri sürülebilir. Halkla ilişkilerin kurumsal itibar yönetim sürecindeki işlevleri kabul gören stratejiler bağlamında da ele alınabilir. Buna göre halkla ilişkiler fonksiyonu kriz veya olumsuz tanıtım durumlarında kuruluşun itibarını korumaya yardım etme anlamında reaktif ya da kurum ile paydaşları arasındaki olası sorunları önceden tespit ederek bunları yönetme anlamında proaktif bir strateji bağlamında faaliyetlerde bulunmaktadır. Seçilen strateji aynı zamanda kurumsal itibar yönetimi sürecinde halkla ilişkilere yüklenen işlevi de belirlemektedir. Buna göre reaktif halkla ilişkiler çalışmaları halkla ilişkilerin stratejik mesaj yaratma işlevine denk düşerken proaktif halkla ilişkiler faaliyetleri stratejik karar almada tavsiyelerde bulunmayla ilişkili olduğu görülmektedir (Akbulut, 2011:148-150)

Halkla ilişkilerin kurumsal itibar yönetim sürecindeki bir diğer önemli görevi ise kurumsal itibara ilişkin algıların paydaşlar arasında farklılık gösterebileceği gerçeğine dayanmaktadır. Buna göre bir kuruluşun itibarı çeşitli paydaşların gözünde farklılık göstermektedir. Bu alt itibarlar arasında sürekli bir etkileşim bulunmaktadır ve bu etkileşimler kuruluşun genel itibarını şekillendirir. Halkla ilişkiler bu paydaş grupların her biri ile ayrı ayrı ilgilenerek aralarındaki etkileşimin kurum lehine olmasını sağlayacak tedbirler alması gerekmektedir (Post ve Griffin, 1997:165).

Halkla ilişkilerin kurumsal itibar yönetimi sürecindeki işlevinden başka halkla ilişkiler ile kurumsal itibar arasındaki ilişkinin bir diğer boyutu da halkla ilişkiler uygulamalarının kurumun itibar düzeyine olan katkısına ilişkindir. Bu bağlamda halkla ilişkiler uygulamalarının kurumsal itibara olan etkisi literatürde iki yaklaşım çerçevesinde ele alınmaktadır. Bunlardan birincisi halkla ilişkilerin kurumsal itibar üzerindeki katkısını halkla ilişkiler uygulamaları için yapılan harcamalar bağlamında ortaya koymaya yöneliktir. Bu yaklaşıma göre halkla ilişkiler uygulamaları için yapılan harcamalar arttıkça kuruluşun itibarı da aynı düzeyde ve olumlu yönde etkilenecektir. Ayrıca olumlu bir itibarın işletmenin finansal getirilerine katkı sağlayacağından dolayı halkla ilişkilerin nihai olarak itibar yönetimi aracılığıyla kuruluş için ekonomik değer yaratacağı, bu yaklaşımın diğer bir varsayımı olarak görülmektedir. Halkla ilişkilerin maddi göstergelerinden yola çıkan bu yaklaşımın varsayımları çeşitli araştırmalarla test edilmeye çalışılmıştır. Örneğin Fortune 500 listesinde yer alan işletmeler örneğinden hareketle kurumsal iletişim harcamaları ile itibar arasında bir ilişki olup olmadığını araştırılmış ve araştırma sonucunda bu iki değiş̧en arasında büyük işletmeler hariç anlamlı bir ilişki olmadığ 1 tespit edilmiştir. Halkla ilişkilerin kurumsal itibar üzerindeki etkisini halkla ilişkiler harcamaları ve finansal getiriler bağlamında ortaya koyma girişimleri esasında halkla ilişkiler profesyonellerinin gittikçe artan bir şekilde kuruluş içi veya dışı halkla ilişkiler biriminin kurum için değerini gösterme sorunuyla yüz yüze gelmelerinin bir neticesidir. Diğer bir deyişle halkla ilişkiler profesyonelleri, halkla ilişkiler fonksiyonunun 
işletmeler için ekonomik geçerliliğini ve değerini maddi göstergeler ve itibar kavramı aracıllı̆̆yla kuruluş yönetimine kabul ettirmeye çalışmaktadırlar. Halkla ilişkilerin unsurlarından çoğu soyut varlık niteliğinde olmakla birlikte halkla ilişkiler finansal getiri sağlamaktan çok olası maliyetleri azaltıcı bir fonksiyon olarak görülmektedir. Bu nedenle halkla ilişkilerin kuruluşa sağladığı katkılar maddi göstergeler aracıllğıyla ölçülemeyeceği söylenebilir. Bu türden bir ölçümleme ancak kısa vadeli iletişim programları bağlamında olabilir. Uzun vadede halkla ilişkilerin değerinin ortaya çıkarılması için maddi olmayan göstergeler gerekmektedir. Olumlu bir itibar da uzun vadede elde edilebildiğinden halkla ilişkilerin itibar üzerindeki etkisi veya rolü, halkla ilişkiler harcamaları değil uzun vadede halkla ilişkilerin kuruma sağladığı katkı dolayısıyla ilişkiler bağlamında ortaya konabilir. Bu bakış açısı halkla ilişkilerin kurumsal itibara olan katkısına ilişkin literatürde yer alan ikinci yaklaşımı ifade etmektedir IABC Mükemmellik projesi ise kurumsal itibar ile halkla ilişkiler arasındaki bağlantının en somut şekilde ortaya konduğu çalışma olarak dikkat çekmektedir. Halkla ilişkiler ile itibar arasındaki bağlantıya ilişkin aşağıdaki sonuçlara ulaşılmıştır (Akbulut, 2011:154153):

i. İtibar, kurum ile paydaşları arasındaki ilişkilerin doğrudan bir ürünüdür.

ii. İtibar, paydaşlara iletilen mesajlardan daha çok (iletişim yönlü yaklaşım) kurumsal davranışlardan (davranış yönlü yaklaşım) etkilenir.

iii. Bu nedenle itibar doğrudan yönetilemez.

iv. İtibar, paydaşlara yönelik davranışlar konusunda kurum yönetimini etkileme yoluyla yönetilebilir.

v. Sonuç olarak kurum ile paydaşlar arasındaki ilişkilerin değeri aynı zamanda itibarın değerini de içerir.

\section{Araştırma Metedolojisi}

\subsection{Araştırmanın Amacı ve Önemi}

İşletmeler ve kurumların kamuoyu tarafından nasıl algılandıklarına, nasıl bilindiklerine nasıl tanındıklarına ilişkin bir takım genel kanaatler bulunmaktadır. $\mathrm{Bu}$ genel kanaatler kurumsal itibarı oluşturmaktadır. Kurumsal itibar; imaj, kimlik, kurumsal kültür unsurlarını bünyesinde barındıran genel bir kavramdır. Hedef kitleler tarafından işletme/kurum hakkında hafızalarda oluşan olumlu imaj ve örgütlerin uzun vadede elde ettikleri kurumsal kimlik ve kültür değerleri işletme ve kurumlar için rekabette üstünlük, iç ve dış çevreyle uyum sağlama ürün ve hizmette sürekli gelişen kalite, nitelikli işgücü vb. avantajlar sağlamak için hayati öneme sahip unsurlardır. Örneğin iyi bir itibarı, güçlü bir imajı, iyi bir kurumsal kimliği ve temelli bir kurumsal kültürü olan firmalar ve kuruluşların hedef kitleye arz ettiği ürün ve hizmetlerin talepleri diğer işletme ve kuruluşlara göre daha fazla olmaktadır.

İşletmeler için halkla ilişkiler birimleri hedef kitleye açılan bir kapı olduğundan dolayı bu birimler işletmeye ait kurumsal itibarın ne derecede olduğunu öngörebilen önemli birimlerdir. Çünkü halkla ilişkiler birimlerinin amacına bakacak olursak; kuruluş ile ilgili her türlü sosyal ilişkileri gerçekleştirmek, yeni bir ürün veya hizmeti hedef kitleye arz etmek, hedef kitlenin her türlü özelliğine hakim olmak ve hedef kitlenin kuruluş hakkındaki düşüncelerini ve fikirlerini öğrenmektir. Dolayısıyla kurum ve kuruluşlar için iyi bir halkla ilişkiler kampanyasının kurumsal itibar üzerindeki olumlu etkisi varsayılmakla birlikte buna paralel olarak etkisiz bir halkla ilişkiler biriminin örgütler üzerindeki kurumsal itibar açısından olumsuz etkisi de yine kaçınılmaz bir durum olarak görülmektedir.

$\mathrm{Bu}$ araştırmanın amacı, halkla ilişkilerin kurumsal itibar üzerindeki etkisinin önemini ve sonuçlarını incelemek, aralarındaki etkileşimi tespit etmek ve halkla ilişkiler faaliyetlerinde 
etkinliğin arttırılarak özellikle üst yönetimce etkili bir halkla ilişkiler biriminin oluşturulması ve faaliyetleri neticesinde kurumsal itibar üzerindeki etkisini belirlemektir.

Halkla ilişkiler birimlerinin faaliyetlerini planlarken hangi hedef kitleye nasıl ulaşacağını hangi dili kullanacağını belirlerken onlara hangi yolla ulaşacağını saptarken bir taraftan da bu halkla ilişkiler departmanı olarak bu faaliyetlerde bulunurken işletmenin kurumsal itibarına olumlu ve olumsuz katkı da bulunulacağının farkında olunması gerektiğinin önemli olduğu görülmektedir.

\subsection{Araştırmanın Modeli}

Araştırmanın modeli Şekil 3'de gösterilmiştir.

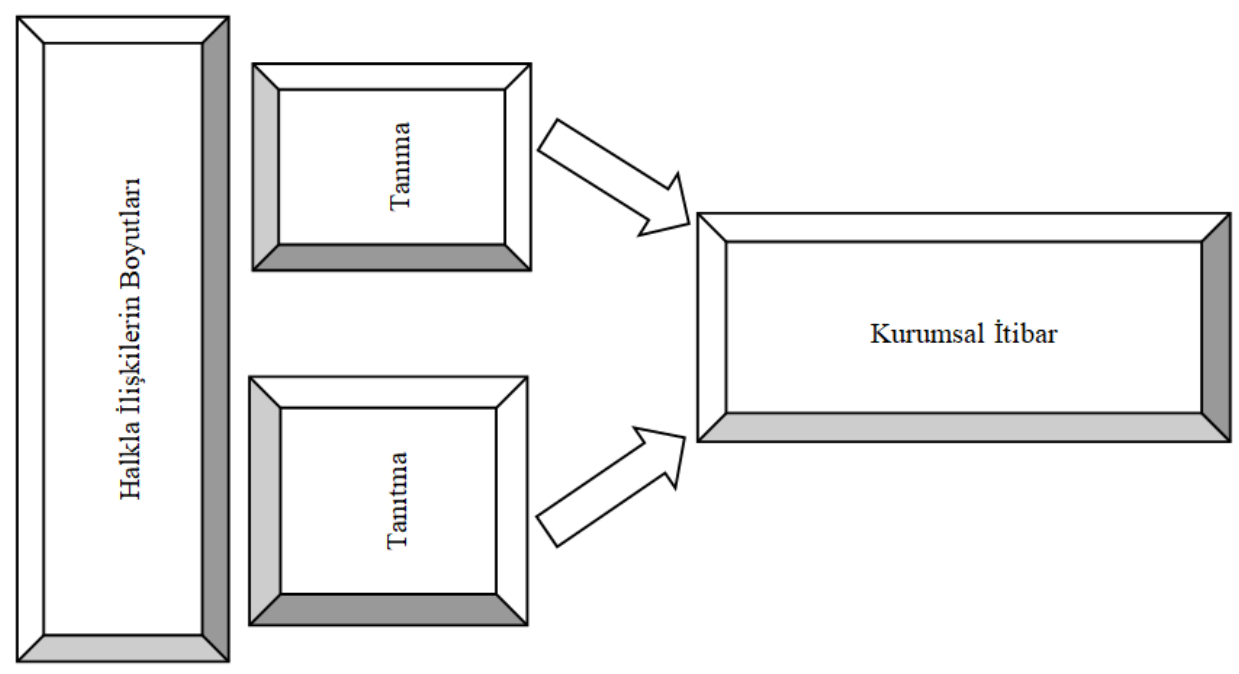

Şekil 3: Araştırmanın Modeli

Yukarıdaki Şekil 3'de görüldüğü gibi halkla ilişkiler boyutlarının, kurumsal itibar üzerindeki etkisine yönelik bir model oluşturulmuştur.

Üzerindeki etkisine yönelik bir model oluşturulmuştur.

Bu modele göre;

i. Halkla ilişkiler boyutları arasında bulunan "tanıma" boyutunun, kurumsal itibar üzerindeki etkisinin var olduğu varsayılmaktadır.

ii. Halkla ilişkiler boyutları arasında bulunan "tanıtma" boyutunun, kurumsal itibar üzerindeki etkisinin var olduğu varsayılmaktadır.

\subsection{Araştırmanın Hipotezleri}

Şekil 3'de gösterilen model baz alınarak halkla ilişkiler boyutlarının kurumsal itibar üzerindeki etkisini ortaya çıkarmak amacıyla oluşturulan hipotezler aşağıda sunulmaktadır.

$\mathrm{H}_{1}=$ Halkla ilişkilerin kurumsal itibar üzerinde anlamlı bir etkisi vardır.

$\mathrm{H}_{1 \mathrm{a}}=$ Halkla ilişkiler boyutlarından "tanıma"nın kurumsal itibar üzerinde anlamlı bir etkisi vardır.

$\mathrm{H}_{1 \mathrm{~b}}=$ Halkla ilişkiler boyutlarından "tanıtma”"nın kurumsal itibar üzerinde anlamlı bir etkisi vardır.

\subsection{Araştırmanın Yöntemi}

$\mathrm{Bu}$ araştırmada veri toplama metodu olarak anket tekniği kullanılmıştır. Anket tekniğinin ekonomik bir veri toplama metodu olması, daha çok veri toplamak için etkin bir yöntem olması, 
kişilerin düşünsel, inançsal, algısal, davranışsal ve güdüsel yönleri hakkında bilgi alınabilmesi ve bu bilgilere hızlı bir şekilde ulaşılabilmesini sağlaması bakımından veri toplama aracı olarak kullanılmıştır (Ural ve Kılıç, 2006: 56).

Anketler bireylere elden verilmiş ve katılımcılardan teslim alınmıştır. Cevaplama yüzdesini artırmak amacıyla anket dağıtılan tüm katılımcılara anket ölçeği verilirken ankette çelişkiye düşecekleri durumlar hakkında detaylı açıklama yapılmıştır. Katılımcılara anketi meşgul olmadıkları bir zamanda, dikkatli bir şekilde okuyarak doldurmaları konusunda tavsiyelerde bulunulmuştur. Anketi doldurmaları için katılımcılara 6 gün süre verilmesi sağlanmıştır.

Anket formları 2 şekilde hazırlanmıştır. Hazırlanan ilk anket Kütahya Belediyesinde çalışan personele uygulanmıştır. Bu anket 2 bölümden oluşmaktadır. Birinci bölümde, yaş, cinsiyet, eğitim düzeyi, Sosyal ağlardan Kütahya Belediyesini takip durumu ve statü gibi çalışanlarla ilgili demografik bilgilerin elde edilmesi amaçlanmıştır. İkinci bölümde ise halkla ilişkiler ve kurumsal itibar ile ilgili ifadelere yer verilmiş ve toplamda 32 ifadeye cevap aranmıştır. Ayrıca anket formunun sonunda Kütahya Belediyesinin Kurumsal itibar algısını ölçmeye yönelik olarak çalışan personelden 1'den 10'a kadar Kütahya Belediyesinin kurumsal itibar algisinı puanlamaları istenmiştir. Araştırmada kullanılan anket formunun örneğine Ek-1'de yer verilmiştir. Hazırlanan ikinci anket ise Kütahya ili Merkez ilçesinde yaşayan ve rasgele seçilen vatandaşlara uygulanmıştır. $\mathrm{Bu}$ anket 2 bölümden oluşmaktadır. Birinci bölümde, yaş, cinsiyet, eğitim düzeyi, sosyal ağlardan Kütahya Belediyesini takip durumu ve statü gibi demografik bilgilerin elde edilmesi amaçlanmıştır. İkinci bölümde ise halkla ilişkiler ile ilgili fadelere yer verilmiş ve toplamda 14 ifadeye cevap aranmıştır. Ayrıca anket formunun sonunda Kütahya Belediyesinin Kurumsal itibar algısını ölçmeye yönelik olarak çalışan personelden 1'den 10'a kadar Kütahya Belediyesinin kurumsal itibar algısını puanlamaları istenmiştir.

Anketteki ölçeklerin oluşturulması için geniş bir literatür incelemesi yapılmış olup, daha önce bu konularda yapılan çalışmalar incelenmiş ve araştırmada kullanılabilecek anket formlarından yararlanılmıştır. Anket sorgusunda katılımcıların cevaplanması istenen ifadelere katılma derecelerini ölçmek için 5'li Likert ölçeği kullanılmış olup,kesinlikle katılmıyorum (1), katılmıyorum (2), kararsızım (3), katılıyorum (4), kesinlikle katılıyorum (5) şeklinde derecelendirme yapılmıştır. Kütahya Belediyesi personeline uygulanan ilk ankette 1.-14.ifadeler halkla ilişkiler, 15.-32. İfadeler ise kurumsal itibar ile ilgili ifadeleri kapsamaktadır. Kurumdaki halkla ilişkileri belirlemeye yönelik "Halkla İlişkiler Ölçeği" ve kurumsal itibarı belirlemeye yönelik ise "Kurumsal İtibar Ölçeği” uygulanması planlanmıştır.

"Halkla İlişkiler Ölçeği” belirlenirken literatürde halkla ilişkiler ile ilgili yapılmış çalışmalar incelenmiş ve " Yerel Yönetimlerde Halkla İlişkiler Faaliyetlerinin Kurum İmajına Etkisi Üzerine Bir Çalışma: Trabzon Belediyesi” adlı Habibe AKÇAY’ın hazırladığı yüksek lisans tezinde kullanılan halkla ilişkiler ölçeği kullanılmıştır.

"Kurumsal İtibar Ölçeği”" olarak kullanılan ölçek ise, Charles J.Fombrun tarafından geliştirilen 18 ifadeden oluşan kurumsal itibar ölçeğidir.Ölçeğin alıntı yapıldığ kaynak Ayşegül GEZMEN'e ait olan 'Kurumsal İtibar Yönetimi ve Kurumsal İtibar Algısının Ölçülmesine Yönelik Bir Araştırma: Türkiye Büyük Millet Meclisi Örneği” konulu yüksek lisans tezidir.

\subsection{Araştırmanın Kapsamı ve Sınırlılıkları}

$\mathrm{Bu}$ araştırma halka hizmet veren bir kuruluş olan ve halkla ilişkilerin en yoğun olarak yaşandığı Kütahya Belediyesinde uygulanmıştır. Çalışma için özellikle belediye seçilmiştir. Çünkü belediyelerin halkla ilişkiler departmanları sürekli aktif olmak ve aynı zamanda verimli olmak zorundadır. Sürekli olarak dış paydaşlarla etkileşim içinde bulunulduğundan halkla ilişkilerin kurumsal itibar üzerindeki etkisi oldukça önemlidir. 
$\mathrm{Bu}$ çalışma Kütahya Belediyesi üst yönetiminden izin alınarak yapılımıştır. Araştırma kapsamında her kademeden çalışanlar bulunmaktadır. Ana kütleyi oluşturan toplam çalışan sayısı 200 olarak tespit edilmiştir. Anket uygulaması zamanı araştırmanın örnek kütlesini teşkil eden belediye çalışanlarına toplam 200 adet anket formu dağıtılmıştır. Anketlerin geri dönüş sayısı 136 adet olmuştur. Eksik doldurulma sebebiyle 8 anket elenmiş, geriye kalan 128 anketteki veriler analiz için uygun bulunmuştur. Araştırma 2 yönlü olarak yapıldığından araştırmanın diğer katılımcıları olan Kütahya ili Merkez ilçesinde yaşayan halka rastgele seçim birebir dağıtılarak uygulanmıştır. Toplam 600 adet anket formu dağıtılmış olup, anketlerin geri dönüş sayısı 508 olmuştur. Eksik doldurma sebebiyle 98 adet anket elenmiş geriye kalan 410 adet anketteki veriler analiz için uygun bulunmuştur.

Araştırma kapsamında gerçekleştirilen anket uygulaması sonucunda elde edilen veriler SPSS for Windows paket programına yüklenerek araştırmanın amacının ortaya çıkarılması maksadıyla çeşitli istatistik analizleri uygulanmıştır. Araştırmada elde edilen veriler güvenilirlik analizi, tanımlayıcı istatistik analizi, T testi ve ANOVA analizleriyle incelenmiştir. Araştırmanın hipotezlerini test etmek amacıyla korelasyon analizi ve regresyon analizlerinden faydalanılmıştır.

Çalışma yapılırken araştırmanın tam anlamıyla gerçekçi sonuçlara ulaşılmasını engelleyen bazı kısıtlar bulunmaktadır. Bu kısıtlar aşağıda sıralanmıştır:

i. Anket uygulaması sırasında katılımcılara, yapılan çalışmanın üyesi oldukları kurum ile paylaşılmayacağı, akademik bir çalışma olduğu ifade edilmesine rağmen çalışanların, araştırma sonuçlarının yönetime verilip, kendilerine olumsuz yansıyabileceği endişesi duyulmuş olabilir. Bu nedenle bazı çekince ve şüphelerle soruları cevaplandırmış olma olasılığ çalışmanın sınırlılığı olarak kabul edilebilir.

ii. Anket uygulamasının tek bir kurumu kapsayacak şekilde yapılmış olması da araştırmanın sınırlılığı olarak kabul edilebilir.

iii. Anket uygulamasının sadece bir il kapsamındaki kurumu kapsayacak şekilde yapılmış olması da araştırmanın sınırlılığ

iv. Araştırmada elde edilen veriler 18-25 Ocak 2016 tarihleri arasında yapılan incelemeye ilişkindir.

\subsection{Araştırmanın Varsayımları}

Yapılan araştırmanın varsayımları aşağıdaki şekilde sıralanabilir:

i. Araştırmanın teorik kısmında yeterli kaynağa ulaşıldığı kabul edilmiştir.

ii. Seçilen araştırma yönteminin; araştırmanın amacına, konusuna ve soruların çözümüne uygun olduğu varsayılmıştır.

iii. Halkla ilişkilerin kurumsal itibar üzerindeki etkisine ilişkin ankette yer alan önermeler, halkla ilişkilerin kurumsal itibar üzerindeki etkisini ortaya koymak için yeterli olduğu varsayılmıştır.

iv. Seçilen örneklem, araştırma evrenini temsil etme bakımından yeterlidir. Çalışanların anket sorularını doğru ve içtenlikle cevapladığı varsayılmıştır.

\section{Bulgular}

Anket yöntemi sonucu elde edilen veriler, güvenilirlilik analizi, ankete katılanların demografik özelliklerine ilişkin bulgular, araştırmada kullanılan değişkenlerin ortalamalarına yönelik bulgular, ANOVA ve T testi bulgularına, araştırmanın hipotezlere ilişkin korelasyon ve regresyon analizi bulgularına ve analiz sonucunda ortaya çıkan model, başlıkları altında incelenecektir. 


\subsection{Güvenilirlik Analizi}

Güvenilirlik analizi, herhangi bir konu hakkında araştırma yapmak istendiğinde araştırmaya seçilen örneklemi oluşturan ifadelerin kendi aralarındaki tutarlılığını test etmek maksadıyla kullanılan analiz yöntemlerinden biridir (Ural ve Kılıç, 2006: 286).

Güvenilirlik analiz sonucunda elde edilen güvenilirlik katsayısı 0 ile 1 arasında değerler almaktadır. Güvenilirlik analizi için Cronbach Alpha, Split- Half, Guttman, Parallel gibi yöntemler kullanılmaktadır. Bunlar arasında en fazla yaygınlık göstereni ise Cronbach Alpha yöntemi olduğundan bu araştırmada Cronbach Alpha yönetmi tercih edilmiştir.

Yapılan analizler sonucunda Cronbach Alpha katsayısı $(\alpha)$ aşă̆ı da gösterildiği gibi yorumlanmaktadır (Uzgören, 2012: 54):

i. $0,00 \leq \alpha<0,40$ ise ölçek güvenilir değil,

ii. $0,40 \leq \alpha<0,60$ ise ölçeğin güvenilirliği düşük,

iii. $0,60 \leq \alpha<0,80$ ise ölçek oldukça güvenilir,

iv. $0,80 \leq \alpha<1,00$ ise ölçek yüksek derecede güvenilir bir ölçektir.

Tablo 5: Halkla İlişkiler ve Kurumsal İtibar Ölçeklerinin Güvenirlilik Analizi Sonuçları

\begin{tabular}{lll}
\hline Ölçekler & Cronbach Alpha Katsayisi & İfade Sayısı \\
\hline Halkla İlişkiler & 0,93 & 14 \\
Kurumsal İtibar & 0,92 & 18 \\
\hline
\end{tabular}

Araştırmada kullanılan halkla ilişkiler ve kurumsal itibar ölçeklerinin güvenilirlik analizlerine ilişkin bulgular Tablo 5'de gösterilmiştir. Tablo 5'e göre halkla ilişkiler ve kurumsal itibar ölçekleri "oldukça güvenilir" olduğu tespit edilmiştir.

Araştırmada kullanılmış olan "Halkla ilişkiler" ve "Kurumsal İtibar" anketlerinin güvenilirliğini ölçmek için 30 denek üzerinde bir ön test yapılarak pilot uygulama gerçekleştirilmiştir. Ön test sonucu elde edilen veriler SPSS for Windows istatistik paket programında değerlendirilmiştir ve güvenilirlik analizi sonucunda 30 değişkenli anketlerden Halkla İlişkiler anketinin cronbach alpha değeri 0,924 olarak, Kurumsal itibar anketinin cronbach alpha değeri 0,91,7 olarak bulunmuştur. $\mathrm{Bu}$ değer kabul sınırlılıklarına oldukça üstünde olduğundan anketler güvenilir sayılmış ve uygulamada kullanılması uygun görülmüştür.

"Yerel Yönetimlerde Halkla İlişkiler Faaliyetlerinin Kurum İmajına Etkisi Üzerine Bir Çalışma: Trabzon Belediyesi" konulu Habibe AKÇAY'a ait olan ve 2010 yılında yazılmış tezde halkla ilişkiler boyutu iki boyut olarak belirlenmiştir. Bu çalışmada da halkla ilişkiler için iki boyut belirlenmiştir.

Bu boyutlar; edilmesidir.

1. Faktör; Tanıma : Kuruluşun, yapmış olduğu hizmetlere yönelik tepkilerin, halktan elde

2. Faktör; Tanıtma : Kuruluşun sağlamış olduğu hizmetlerin, kolaylıkların, faaliyetlerin halka aktarılma yöntemlerinin tümünü ifadesidir.

Tablo 6'de Halkla İlişkiler Boyutlarının İfadelere Göre Dağılımı verilmiştir. 
Tablo 6: Halkla İlişkiler Boyutlarının İfadelere Göre Dağılımı

\begin{tabular}{ll}
\hline Faktör & Ifade \\
\hline & 1. Belediye hizmetleriyle ilgili bir sorunum olduğu zaman Belediye'nin halkla ilişkiler \\
birimine danışırım. & 2. Belediye tarafından çıkarılan ilan, dergi, broşür vb. yayınlardan haberdar oluyorum. \\
3. Belediye tarafından çıkarılan ilan, dergi, broşür vb. yayınlara genellikle \\
ulaşabilmekteyim. \\
4. Kütahya Belediyesi’nin bir vatandaş olarak benim ihtiyaçlarımı dikkate alacağını beni \\
dinleyeceğini düşünüyorum. \\
5. Basında Kütahya Belediyesi ile ilgili olarak çıkan haber daha çok ilgimi çekiyor. \\
6. Kütahya Belediyesinin İnternet (Web) sitesini işe yarar buluyorum. \\
7. Kütahya Belediyesinin İnternet (Web) sitesinden yararlanırım. \\
8. Bir Problemimin çözümü için Kütahya Belediyesine Mail (e-Posta) ile başvuru \\
yapıyorum. \\
9. Bir problemimin çözümü için Kütahya Belediyesinin çağrı merkezinden (santral) \\
faydalanırım. \\
10. Kütahya Belediyesinin dilek ve şikayet kutularını işe yarar buluyorum. \\
11. Belediyede vatandaşın istek ve şikayetlerini bildirebileceği "Beyaz Masa" isminde bir \\
birimin olduğunu daha önce duydum. \\
12. Belediyeyle ilgili herhangi bir isteğim ya da şikayetim olduğunda "Beyaz Masa"dan \\
faydalanırım. \\
13. Belediyenin düzenlemiş olduğu halk günü vb. halkı şikayetlerini dinleme amaçlı \\
faaliyetlerinden haberdar olmaktayım. \\
14. Belediyenin düzenlemiş olduğu halk günü vb. Halkı şikayetlerini dinleme amaçlı \\
faaliyetlerine katılmak isterim.
\end{tabular}

\subsection{Demografik Değişkenlere İlişkin Tanımlayıcı İstatistikler}

Tablo 7'de ankete katılan bireylerin demografik özelliklerine ait bilgiler verilmiştir. Katılımcılarınçalışma süresi, cinsiyet ve eğitime göre dağılımı belirlenmiştir.

Tablo 7: Ankete Katılan Bireylerin Demografik Özellikleri

\begin{tabular}{|c|c|c|c|c|c|c|}
\hline \multirow{2}{*}{ Statü } & \multirow{2}{*}{ Yaş } & \multicolumn{4}{|c|}{ Ĕgitim } & \multirow{2}{*}{ Toplam } \\
\hline & & İlköğretim & Lise & Önlisans & Lisans & \\
\hline \multirow{4}{*}{ Yönetici } & 25 ve altı & 4 & 1 & 0 & 0 & 5 \\
\hline & $26-34$ & 3 & 2 & 5 & 10 & 20 \\
\hline & $35-44$ & 3 & 0 & 4 & 12 & 19 \\
\hline & 45 ve üstü & 1 & 1 & 3 & 11 & 16 \\
\hline \multirow{4}{*}{ Çalışan } & 25 ve altı & 13 & 25 & 11 & 2 & 51 \\
\hline & $26-34$ & 13 & 56 & 22 & 47 & 138 \\
\hline & $35-44$ & 11 & 34 & 15 & 22 & 82 \\
\hline & 45 ve üstü & 5 & 11 & 6 & 5 & 27 \\
\hline \multirow{3}{*}{ Öğrenci } & 25 ve altı & 0 & 24 & 16 & 12 & 52 \\
\hline & $26-34$ & 1 & 7 & 4 & 4 & 16 \\
\hline & $35-44$ & 0 & 3 & 3 & 0 & 6 \\
\hline \multirow{4}{*}{ Diğer } & 25 ve altı & 9 & 10 & 5 & 0 & 24 \\
\hline & $26-34$ & 5 & 15 & 8 & 6 & 34 \\
\hline & $35-44$ & 5 & 9 & 3 & 1 & 18 \\
\hline & 45 ve üstü & 9 & 11 & 5 & 5 & 30 \\
\hline \multirow{4}{*}{ Toplam } & 25 ve altı & 26 & 60 & 32 & 14 & 132 \\
\hline & $26-34$ & 22 & 80 & 39 & 67 & 208 \\
\hline & $35-44$ & 19 & 46 & 25 & 35 & 125 \\
\hline & 45 ve üstü & 15 & 23 & 14 & 21 & 73 \\
\hline
\end{tabular}


Elde edilen bulgular neticesinde katılımcıların 16'sının 45 yaş ve üstü, 19'unun 35-44 aras1, 20'sinin 26-34 yaş arası, 5'inin 25 ve altı yaş aralığında, yönetici statüsünde bulunan kişilerden oluştuğu görülmektedir. Katılımcıların 60'1 yönetici, 298'i çalışan, 74'ü öğrenci, 106's1 diğer statüde bulunmaktadır. Katılımcıların statüleri içinde en yüksek paya çalışanların sahip olduğu görülmektedir. Katılımcıların 82'si ilköğretim, 209'u lise, 110'u önlisans, 137'si lisans eğitim düzeyine sahiptir. Eğitim düzeyinde en yüksek paya lise mezunlarının sahip olduğu görülmektedir.

\subsection{Halkla İlişkiler Boyutları İçin İstatistiksel Bulgular}

Tablo 8'de halkla ilişkiler boyutlarından "tanıma" ve "tanıtma" ifadelerinin aritmetik ortalamaları ve standart sapmaları istatistiksel olarak gösterilmiştir.

Tablo 8: Halkla İlişkiler Boyutları İçin Bulgular

\begin{tabular}{|c|c|c|}
\hline Tanıma Boyutu & $\begin{array}{l}\text { Aritmetik } \\
\text { Ortalama }\end{array}$ & $\begin{array}{c}\text { Standart } \\
\text { Sapma }\end{array}$ \\
\hline $\begin{array}{l}\text { Belediye hizmetleriyle ilgili bir sorunum olduğu zaman Belediye'nin halkla } \\
\text { ilişkiler birimine danışırım. }\end{array}$ & 2,98 & 1,36 \\
\hline $\begin{array}{l}\text { Belediye tarafından çıkarılan ilan, dergi, broşür vb. yayınlardan haberdar } \\
\text { oluyorum. }\end{array}$ & 3,05 & 1,28 \\
\hline $\begin{array}{l}\text { Belediye tarafından çıkarılan ilan, dergi, broşür vb. yayınlara genellikle } \\
\text { ulaşabilmekteyim. }\end{array}$ & 3,14 & 1,29 \\
\hline $\begin{array}{l}\text { Kütahya Belediyesi'nin bir vatandaş olarak benim ihtiyaçlarımı dikkate } \\
\text { alacağını beni dinleyeceğini düşünüyorum. }\end{array}$ & 3,33 & 1,29 \\
\hline $\begin{array}{l}\text { Basında Kütahya Belediyesi ile ilgili olarak çıkan haber daha çok ilgimi } \\
\text { çekiyor. }\end{array}$ & 3,44 & 1,24 \\
\hline Tanitma Boyutu & $\begin{array}{l}\text { Aritmetik } \\
\text { Ortalama }\end{array}$ & $\begin{array}{l}\text { Standart } \\
\text { Sapma }\end{array}$ \\
\hline Kütahya Belediyesinin İnternet (Web) sitesini işe yarar buluyorum. & 3,38 & 1,24 \\
\hline Kütahya Belediyesinin İnternet (Web) sitesinden yararlanırım. & 3,32 & 1,26 \\
\hline $\begin{array}{l}\text { Bir Problemimin çözümü için Kütahya Belediyesine Mail (e-Posta) ile } \\
\text { başvuru yapıyorum. }\end{array}$ & 3,03 & 1,29 \\
\hline $\begin{array}{l}\text { Bir problemimin çözümü için Kütahya Belediyesinin çağrı merkezinden } \\
\text { (santral) faydalanırım. }\end{array}$ & 3,27 & 1,27 \\
\hline Kütahya Belediyesinin dilek ve şikâyet kutularını işe yarar buluyorum. & 3,19 & 1,25 \\
\hline $\begin{array}{l}\text { Belediyede vatandaşın istek ve şikâyetlerini bildirebileceği "Beyaz } \\
\text { Masa"isminde bir birimin olduğunu daha önce duydum. }\end{array}$ & 3,40 & 1,31 \\
\hline $\begin{array}{l}\text { Belediyeyle ilgili herhangi bir isteğim ya da şikâyetim olduğunda "Beyaz } \\
\text { Masa"dan faydalanırım. }\end{array}$ & 3,24 & 1,33 \\
\hline $\begin{array}{l}\text { Belediyenin düzenlemiş olduğu halk günü vb. halkı şikâyetlerini dinleme } \\
\text { amaçlı faaliyetlerinden haberdar olmaktayım. }\end{array}$ & 3,05 & 1,31 \\
\hline $\begin{array}{l}\text { Belediyenin düzenlemiş olduğu halk günü vb. Halkı şikâyetlerini dinleme } \\
\text { amaçlı faaliyetlerine katılmak isterim. }\end{array}$ & 3,53 & 1,25 \\
\hline
\end{tabular}

\subsubsection{Hipotezlerin Test Edilmesi}

Çalışmanın bu bölümünde araştırma için oluşturulan hipotezler korelasyon ve regresyon analizleri yardımıyla test edilecek ve Kütahya Belediyesinde halkla ilişkilerin kurumsal itibar üzerindeki etkisine değinilecektir.

\subsubsection{Halkla İliş̧kiler ve Kurumsal İtibarDeğişkenleri İçin Korelasyon Analizi}

Korelasyon analizi, aralık ve rasyo seviyesinde ölçülmüş iki değişken arasındaki ilişkinin veya bağımlılığın şiddetini belirlemeye yönelik bir analiz tekniğidir. Korelasyon analizinde ölçülmeye 
çalışılan ilişki, değişkenler arasındaki ilişkinin doğrusal olan kısmı ile ilgilidir (Altunışık vd. 2007:199-200) Bu analizde halkla ilişkiler boyutlarının kurumsal itibar üzerindeki etkisi ölçülmektedir.

Tablo 9: Korelasyon Analizine İlişkin Bulgular

\begin{tabular}{|c|c|c|c|c|}
\hline & & Tanıma & Tanitma & Kurumsal_itibar \\
\hline & Pearson Korelasyon & 1 & $0,77^{* *}$ & $0,77^{* *}$ \\
\hline \multirow[t]{3}{*}{ Tanıma } & Sig. (2-tailed) & & 0,000 & 0,000 \\
\hline & $\mathrm{N}$ & 538 & 538 & 128 \\
\hline & Pearson Korelasyon & $0,77^{* *}$ & 1 & $0,79^{* *}$ \\
\hline \multirow[t]{3}{*}{ Tanitma } & Sig. (2-tailed) & 0,000 & & 0,000 \\
\hline & $\mathrm{N}$ & 538 & 538 & 128 \\
\hline & Pearson Korelasyon & $0,77^{* *}$ &, $79^{* *}$ & 1 \\
\hline \multirow[t]{2}{*}{ Kurumsal_itibar } & Sig. (2-tailed) & 0,000 &, 000 & \\
\hline & $\mathrm{N}$ & 128 & 128 & 128 \\
\hline
\end{tabular}

Tablo 9'da korelasyon analizi verilmiştir. Boyutlararası ilişki düzeyi belirtilmiştir. İlişki düzeyleri çok zayıf, zayıf, orta, yüksek ve çok yüksek olarak belirlenmiştir. Kurumsal itibar ile; tanıma arasında yüksek, kurumsal itibar ile tanıtma arasında yüksek, tanıma ve tanıtma arasında yüksek pozitif yönlü bir ilişki düzeyi bulunmuştur. Görüldüğü gibi kurumsal itibar ile halkla ilişkiler boyutları arasından tanıtmanın daha fazla ilişkisi olduğu görülmektedir.

Tablo 10: Pearson Korelasyon Katsayisı Yorumu

\begin{tabular}{ll}
\hline Pearson Korelasyon Katsayısı (r) & İlişki \\
\hline $0,00-0,25$ & Çok Zayıf \\
$0,26-0,49$ & Zayıf \\
$0,5-0,69$ & Orta \\
$0,7-0,8$ & Yüksek \\
$0,9-1$ & Çok Yüksek \\
\hline
\end{tabular}

Kaynak:https://kemaldoymus.files.wordpress.com/2009/12/korelasyon.ppt, 2016.

\subsubsection{Halkla İlişkiler ve Kurumsal İtibar Değişkenleri İçin Çoklu Regresyon Analizi}

Kurumsal itibar ve halkla ilişkilerin birbirleri üzerindeki etkisi araştırılmıştır. Bunun için ilk önce halkla ilişkilerin 2 boyutu ve kurumsal itibar arasında çoklu regresyon analizi yapılmıştır.

Kurumsal itibarın bağımlı, halkla ilişkilerin bağımsız değişken olduğu çoklu regresyon modeli kurularak halkla ilişkiler boyutlarının kurumsal itibarı açıklaması incelenmiştir. Tablo 11'de kurumsal itibar için çoklu regresyon analiz gösterilmiştir.

Tablo 11: Kurumsal İtibar İçin Çoklu Regresyon Analizi

\begin{tabular}{lllllll}
\hline & Model & B & Standart Sapma & Beta & t & Sig. \\
\hline \multirow{3}{*}{1} & Sabit Değişken & 0,23 & 0,22 & & 1,05 & 0,30 \\
& Tanıma & 0,40 & 0,08 & 0,38 & 4,70 & 0,00 \\
& Tanıtma & 0,56 & 0,09 & 0,49 & 6,04 & 0,00 \\
\hline
\end{tabular}

a. Bağımlı Değişken: kurumsal_itibar

$\mathrm{R}^{2}=0,45 \mathrm{R}=0,62 \mathrm{sig}=0,000$ 
Tablo 11'de kurulacak olan çoklu regresyon modeli Kurumsal İtibar $=0,23+0,56$ tanıtma +0,4 tanımaolarak gerçekleşmiştir. Kurulan modelin açıklama düzeyi 0,45 olarak belirlenmiştir.

Tablo 12'de regresyon analizi hipotez sonuçlarıgösterilmiştir.

Tablo 12: Regresyon Analizi Hipotez Sonuçları

$\mathrm{H}_{1 \mathrm{a}}=$ Halkla İlişkiler Boyutlarından Tanıma'nın Kurumsal İtibar üzerinde pozitif etkisi vardır. $\quad$ Kabul

$\mathrm{H}_{1 \mathrm{~b}}=$ Halkla İlişkiler Boyutlarından Tanıtma'nın Kurumsal İtibar üzerinde pozitif etkisi vardır. Kabul

Çoklu regresyon analizi sonucunda $\mathrm{H}_{1 \mathrm{a}}$ ve $\mathrm{H}_{1 \mathrm{~b}}$ hipotezleri kabul görmektedir. Kurumsal itibar üzerinde halkla ilişkiler boyutlarından "tanıma" ve "tanıtma" boyutlarının pozitif yönde etkisinin olduğuna ulaşılmıştır.

Bunun neticesinde, araştırma hipotezlerinin test edilmesi sonucu oluşan nihai model Şekil 4'deki gibi belirlenmiştir.
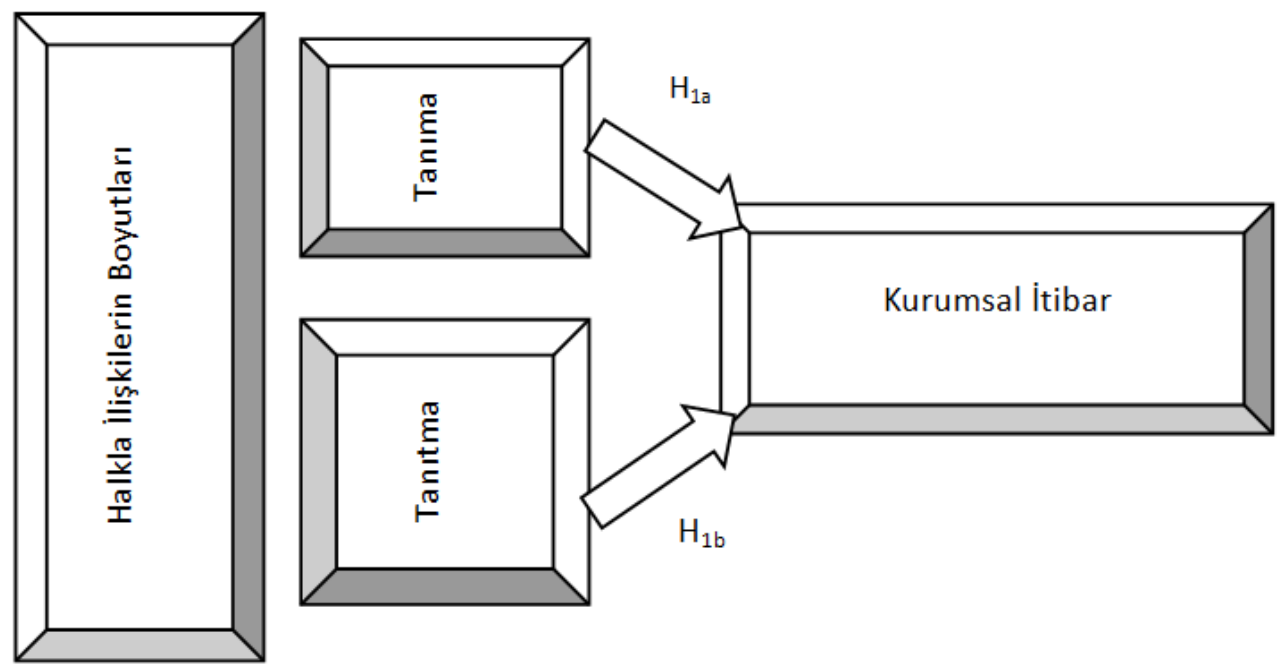

Şekil 4: Araştırma Hipotezlerinin Test Edilmesi Sonucu Oluşan Nihai Model sahiptir.

Şekil 4'e göre Kurumsal itibar üzerinde Tanıma ve Tanıtma boyutları olumlu bir etkiye

Halkla ilişkiler boyutlarından tanıtmanın kurumsal itibar üzerinde etkisinin son derece önemli olduğunu söylemek mümkündür. Çünkü tanıtma kurumun; faaliyetlerini hizmetlerini, olumlu yönlerini hedef kitleye aktarma kısacası reklam yapmaktır. Dolayısıyla tanıtma faaliyetlerine kurum ne kadar önem verirse hedef kitledeki itibarı, saygınlığı, imajı o derece pozitif yönde artacaktır. Halkla ilişkiler boyutlarından tanıma ise tanıtma boyutuna göre etkisi az olmakla birlikte kuruluş tarafından önemsenecek seviyede bulunmaktadır. Tanıma kuruluşun hedef kitle tarafından bilinebilirlik düzeyidir. Diğer bir deyişle hedef kitle kuruluş hakkında ne kadar bilgiye sahip, kurulușun amacını, hedefini, görevini, özelliklerini, sunduğu hizmetleri hangi bildiği ile ilgilidir. Dolayısıyla tanıma itibar ile bağlı bir boyuttur. Çünkü hedef kitle itibarlı olarak gördükleri kuruluşları daha iyi araştırma yoluna giderler. Onun kimliğini, özelliklerini, hedeflerini, faaliyetlerini, hizmetlerini daha çok merak ederler. Dolayısıyla itibar dolaylı olarak yine kuruluşu etkileyecek güce sahip bir durumdadır.

Kısacası kuruluşlar halkla ilişkiler faaliyetlerine önem vermek zorundadırlar. Çünkü halkla ilişkiler faaliyetleri kurumsal itibar ile sıkı bir ilişki içerisindedir. Ve her kuruluşun hedefleri arasında kesinlikle hedef kitle üzerinde iyi bir itibar sahibi olmak vardır. Ve bu iyi itibara ulaşmanın en önemli yollarından birisi de halkla ilişkiler faaliyetlerine önem vermek, halkla ilişkiler faaliyetlerini sürekli olarak geliştirmekten geçmektedir. 
Demografik özellikler için fark analizleri ANOVA ve $\mathrm{T}$ testleriyle tespit edilmiş olup, Tablo 13'de gösterilmiştir.

Tablo 13: Demografik Özellikler İçin ANOVA ve T Testleri Sonuçları

\begin{tabular}{|c|c|c|c|c|}
\hline Halkla İlişkiler Boyutları & Test Türü & $\mathbf{F}$ & $\mathbf{P}$ & Sonuç \\
\hline Katılımcıların yaşlarına göre tanımada fark vardır. & ANOVA & 2,73 & 0,04 & Var \\
\hline Katılımcıların yaşlarına göre tanıtmada fark vardır. & ANOVA & 3,23 & 0,02 & Var \\
\hline Katılımcıların cinsiyetine göre tanımada fark vardır. & T Testi & 0,75 & 0,38 & Yok \\
\hline Katılımcıların cinsiyetine göre tanıtmada fark vardır. & T Testi & 8,09 & 0 & Var \\
\hline Katılımcıların eğitimine göre tanımada fark vardır. & ANOVA & 2,32 & 0 & Var \\
\hline Katılımcıların eğitimine göre tanıtmada fark vardır. & ANOVA & 2,61 & 0,05 & Var \\
\hline Katılımcıların sosyal takibine göre tanımada fark vardır. & T Testi & 2,04 & 0 & Var \\
\hline Katılımcıların sosyal takibine göre tanıtmada fark vardır. & T Testi & 3,72 & 0 & Var \\
\hline Katılımcıların statüsüne göre tanımada fark vardır. & ANOVA & 3,729 & 0,01 & Var \\
\hline Katılımcıların statüsüne göre tanıtmada fark vardır. & ANOVA & 3,348 & 0,02 & Var \\
\hline Kurumsal İtibar & Test Türü & $\mathbf{F}$ & $\mathbf{P}$ & Sonuç \\
\hline \multirow{5}{*}{$\begin{array}{l}\text { Katılımcıların yaşlarına göre kurumsal itibarda fark vardır. } \\
\text { Katılımcıların cinsiyetine göre kurumsal itibarda fark } \\
\text { vardır. } \\
\text { Katılımcıların eğitimine göre kurumsal itibarda fark vardır. } \\
\text { Katılımcıların sosyal takibine göre kurumsal itibarda fark } \\
\text { vardır. } \\
\text { Katılımcıların statüsüne göre kurumsal itibarda fark vardır. }\end{array}$} & ANOVA & 2,5 & 0,05 & Var \\
\hline & T Testi & 3,14 & 0,08 & Yok \\
\hline & ANOVA & 3,936 & 0,01 & Var \\
\hline & T Testi & 2,16 & 0,05 & Yok \\
\hline & T Testi & 3,58 & 0,01 & Var \\
\hline
\end{tabular}

Katılımcıların yaşlarına göre tanımada anlamlı bir fark vardır. 25 yaş ve altı için 3,01; 45 yaş ve üzeri için 3,44 ortalamalarla aralarında tanıma açısından anlamlı bir fark vardır. Katılımcıların yaşlarına göre tanıtmada anlamlı bir fark vardır. 25 yaş ve altı için 3,05; 26 - 34 yaş arası için 3,$32 ; 35$ - 44 yaş arası için 3,$33 ; 45$ yaş ve üzeri için 3,4 ortalamalarla aralarında tanıma açısından anlamlı bir fark vardır. Katılımcıların yaşlarına göre kurumsal itibarda anlamlı bir fark vardır. 25 yaş ve altı için 4,05; 45 yaş ve üzeri için 3,29 ortalamalarla aralarında kurumsal itibar açısından anlamlı bir fark vardır. Katılımcıların yaşlarına göre tanımada anlamlı bir fark vardır. 35 - 44 yaş arası için 3,97; 45 yaş ve üzeri için 3,29 ortalamalarla aralarında tanıma açısından anlamlı bir fark vardır.

Katılımcıların cinsiyetine göre tanıtmada anlamlı bir fark vardır. Erkekler için 3,28; kadınlar için 3,25 ortalamalarla aralarında tanıma açısından anlamlı bir fark vardır.

Katılımcıların eğitimine göre kurumsal itibarda anlamlı bir fark vardır. İlköğretim mezunları için 4,23; lise mezunları için 4,04; önlisan mezunları için 3,57; lisans mezunları için 3,52 ortalamalarla ilköğretim - önlisans, ilköğretim - lisans, lise - önlisans, lise - lisans mezunu aralarında kurumsal itibar açısından anlamlı bir fark vardır. Katılımcıların eğitimine göre tanıtmada anlamlı bir fark vardır. İlköğretim mezunları için 3; lise mezunları için 3,31; önlisan mezunları için 3,34; lisans mezunları için 3,29 ortalamalarla ilköğretim - önlisans, ilköğretim - lise, ilköğretim lisans mezunu aralarında kurumsal itibar açısından anlamlı bir fark vardır. Katılımcıların eğitimine göre tanımada anlamlı bir fark vardır. İlköğretim mezunları için 2,9; lise mezunları için 3,2; önlisan mezunları için 3,24; lisans mezunları için 3,28 ortalamalarla ilköğretim - önlisans, ilköğretim lise, ilköğretim - lisans mezunu aralarında tanıma açısından anlamlı bir fark vardır.

Katılımcıların sosyal takibine göre tanımada anlamlı bir fark vardır. Sosyal medya takip edenler için 3,53; sosyal medya takip etmeyenler için 2,71 ortalamalarla aralarında tanıma açısından anlamlı bir fark vardır. Katılımcıların sosyal takibine göre tanıtmada anlamlı bir fark vardır. Sosyal medya takip edenler için 3,56; sosyal medya takip etmeyenler için 2,85 ortalamalarla aralarında tanıtma açısından anlamlı bir fark vardır. 
Katılımcıların statüsüne göre tanımada anlamlı bir fark vardır. Yönetici için 3,44; çalışan için 3,25; öğrenci için 2,89; diğer için 3,08 ortalamalarla yönetici - öğrenci, yönetici - diğer; çalışan - öğrenci aralarında tanıma açısından anlamlı bir fark vardır. Katılımcıların statüsüne göre tanıtmada anlamlı bir fark vardır. Yönetici için 3,47; çalışan için 3,32; öğrenci için 3,05; diğer için 3,13 ortalamalarla yönetici - öğrenci, çalışan - öğrenci, diğer - yönetici aralarında tanıtma açısından anlamlı bir fark vardır.

\section{Sonuc}

Günümüz dünyasında kuruluşların faaliyette bulundukları çevrelerinde çok hızlı ve sürekli olarak ekonomik, sosyal değişim ve gelişmeler olmaktadır. Kuruluşların varlıklarını sürdürebilmeleri için yaşanan bu hızlı değişime ayak uydurmaları gerekmektedir. $\mathrm{Bu}$ da ancak etkili ve başarılı bir yönetim yolu ile mümkün olabilir. Kuruluşların hedeflerine ulaşabilmelerindeki başarı kriterlerinden başında kuruluşun çevresiyle iyi bir iletişimde bulunması gelmektedir. Kurumun çevredeki çıkar ve baskı grupları olarak nitelendirilen müşteriler, rakipler, sendikalar, diğer kurum ve kuruluşlar, devlet ve diğer kamu otoriteri, gönüllü kuruluşlar, meslek kuruluşları vb. gibi gruplarla iyi ilişsiler kurması gerekmektedir. Kurumun başarısı için bu grupların çıkarlarının, istek ve tepkilerinin gözetilerek iyi analiz edilmesi ve bu grupların güven ve desteklerinin sağlanması hususu gün geçtikçe önem kazanmaktadır. Bu bağlamda kurumların iletişim görevini üstlenen halkla ilişkiler birimleri işletmeler için çok önemli bir yönetim fonksiyonu olarak karşımıza çıkmaktadır.

Kuruluşlar halkla ilişkiler birimleri aracılığı ile ürettikleri ürün ve hizmetlerin bilgisini hedef kitleye arz ederler. Ve yine üretilen mal ve hizmetler ile ilgili hedef kitleden gelen tepkileri halkla ilişkiler birimleri aracılığı ile öğrenirler. Burada görülmektedir ki halkla ilişkiler birimlerinin en temel görevi üretilen mal ve hizmetlerin bilgisini hedef kitleye aktarmak ve gelen tepkileri de kurulaşa sunmaktır. Bu döngü ne kadar sık olursa halkla ilişkiler uygulamalarında başarıyı yakalamak ta o derece yüksek olacaktır.

1900’lü yıllardan önce kuruluşlar tarafından sınırlı olarak üretilen ürün ve hizmetler için tüketici bulmak zor bir iş değildi. Dolayısıyla kuruluşlar ürettikleri ürün ve hizmetleri hedef kitleye tanıtma gereksinimi duymamakla birlikte üretilen mal ve hizmetlerin üretim aşamasında tüketicilerin algı ve beklentileri de dikkate alınmamaktaydı. Ve bu durumda kurumlar günümüzde bu iletişimi sağlayan halkla ilişkiler birimlerine ihtiyaç duymamaktaydılar. Fakat teknolojik alanda yaşanan gelişmelere paralele olarak sanayide yaşanan değişimler ve dolayısıyla artan ürün ve hizmetler tüketicilere seçme hakkı tanımaya başladı. Ve artık kuruluşlar bazı faktörlere göre tüketiciler tarafından tercih edildikleri için sahip oldukları özelliklerini, ürettikleri ürünün ve hizmetin iyi yönlerini, fiyatını, cinsini, faydalarını üstünlüklerini rakiplerine avantaj sağlamak için halka tanıtma ihtiyacı hissetmektedirler. Halkla ilişkeler birimlerinin gösterdikleri performanslarının derecesine göre bünyesinde faaliyette bulundukları kurumlarına katkı sağlamaktadırlar. İyi bir halkla ilişkiler uygulaması ile hedef kitle tarafından kuruluşun ürün ve hizmetinin tercih edilmesi ve bu tercih sayısı arttıkça işletmenin ününün de artması ve kuruluşun faaliyette bulunduğu çevresinde iyi bir itibara kavuşması öngörülen bir durumdur. İtibarı iyi olan bir kurum ürettiği ürün ve hizmetlerin pazarlamasında avantaj elde edeceği ve itibarlı olduğundan dolayı nitelikli iş gücüne sahip olacağı değerlendirilmektedir.

Günümüzde ürün ve hizmetlerin birbirlerine benzediklerinden dolayı kurumlar arasında avantaj sağlayacak, rekabet gücü kazandıracak farkl1lı̆̆ kurumun sahip olduğu itibarı sağlamaktadır. Hedef kitlesini algılamalarının toplamından oluşan kurumsal itibar kurumun en önemli sermayesidir. Geçmişin geçerli olan terimi "büyük" olmak artık "beğenilen" olmak olarak değişmiştir. Büyüklük mevcut durumu ve geçmişi yansitır ama beğenilen olmak gelecek için kurumlara güven aşılar. Olumlu itibar kuruluşa nitelikli insan kaynağına sahip olma, rakiplerine oranla daha yüksek fiyat belirleme imkanı, finansal piyasalarda kredibilite yükseltme olanağı, daha 
kolay yatırımcı kazanma gibi bir takım yararlar sağlar. Özetle itibar kuruma değer katar denilebilir. Araştırmalar göstermektedir ki bir kuruluşun finansal göstergelerinde hiçbir değişiklik olmaksızın salt kurumsal itibarı, sermaye piyasasında işlem gören hisse senetlerinin değerini $\% 15$ oranında etkileyebilmektedir.

Olumlu bir kurumsal itibar kamuoyu önünde yüksek görünürlülük gerektirir. Bu nedenle itibar yaratmada iletişim önemli bir faktördür. $\mathrm{Bu}$ iletişim işlevini yerine getirin birim ise kurumlarda halkla ilişkiler birimleridir. Bu nedenle halkla ilişkiler uygulamalarının etkin ve verimli bir şekilde gerçekleştirilmesinin kurumsal itibara katkı sağlayacağı yadsınamaz bir gerçektir.

$\mathrm{Bu}$ araştırma halkla ilişkilerin kurumsal itibar üzerindeki etkisinin önemini ve yol haritasını belirlemek, aralarındaki etkileşimi tespit etmek amacıyla yapılmıştır. Bu konuda literatür taraması yapılmış ve bu konudaki yaklaşımlar istatistik analiz ile test edilmiştir. Halkla ilişkilerin kurumsal itibar üzerindeki etkisini ortaya çıkarmak için hazırlanan anket sorularına yanıt aramak amacıyla bir hizmet kuruluşu olan Kütahya Belediyesi çalışanlarına ve rastgele seçilen Kütahya Merkez ilçede yaşayan vatandaşlara anket uygulaması yapılmıştır. 128 çalışan ve 410 vatandaş üzerinde uygulanan bu araştırma sonucunda halkla ilişkilerin kurumsal itibar üzerindeki etkisi incelenmiş, kavramlar arasındaki ilişkinin boyutları, halkla ilişkilerin kurumsal itibar üzerindeki etkisi yapılan anket uygulaması sonucu irdelenmeye çalışılmıştır.

Araştırma yöntemi sonucunda, halkla ilişkilerin kurumsal itibar üzerindeki etkisine yönelik ileri sürülen hipotezler test edilmiş, araştırmaya katılan kişilerin demografik özellikleri frekans dağılımları şeklinde gösterilmiş̧tir.

Halkla ilişkilerin tanıma ve tanıtma boyutları ile kurumsal itibar arasındaki ilişki düzeyini tespit edebilmek için korelasyon testi yapılmış, elde edilen bulgularla, halkla ilişkiler boyutlarının kurumsal itibar üzerindeki etkisini değerlendirmeye yönelik regresyon analizi ile hipotezler kurulmuştur. Bu araştırmadaki sınırlılıklar, kullanılan anket yönteminin özellikleri, uygulandığ1 Kütahya Belediyesi bünyesinde çalışmanın yapıldığı zaman dilimi içerisindeki görev yapan kişiler, ve anket uygulaması sırasında katılımcılara, yapılan çalışmanın üyesi oldukları kurum ile paylaşılmayacağı, akademik bir çalı̧̧ma olduğu ifade edilmesine rağmen çalışanların, araştırma sonuçlarının yönetime verilip, kendilerine olumsuz yansıyabileceği endişesi duyulmuş olabilir. Bu nedenle bazı çekince ve şüphelerle soruları cevaplandırmış olma olasılığ 1 çalışmanın sınırlılığ 1 olarak kabul edilebilir. Anket uygulamasının tek bir kurumu kapsayacak şekilde yapılmış olması da araştırmanın sınırlılığı olarak kabul edilebilir. Anket uygulamasının sadece bir il kapsamındaki kurumu kapsayacak şekilde yapılmış olması da araştırmanın sınırlılı̆̆ Araştırmada uygulanan analiz değerlendirmelerinde, çalışanların ve halkın halkla ilişkilerin kurumsal itibar üzerine etkisine yönelik düşünce ve değer yargıları saptanmıştır. Elde edilen bulgular doğrultusunda anket formu uygulanan kişiler açısından halkla ilişkiler uygulamaları ile kurumsal itibar arasında büyük oranda ve olumlu yönde ilişkilerin varlığı gözlenmiştir.

Korelasyon analizi ile tespit edilen boyutlar arası ilişki düzeyinde halkla ilişkiler boyutlarından tanıtmanın diğer boyut olan tanımaya göre kurumsal itibar ile ilişkisi daha yüksek olduğu görülmüştür. Ankette bulunan sorulardan aşağıda verilenler tanıtma boyutu ile ilgili sorulardır.

i. Kütahya Belediyesinin İnternet (Web) sitesini işe yarar buluyorum.

ii. Kütahya Belediyesinin İnternet (Web) sitesinden yararlanırım.

iii. Bir Problemimin çözümü için Kütahya Belediyesine Mail (e-Posta) ile başvuru yapıyorum.

iv. Bir problemimin çözümü için Kütahya Belediyesinin çağrı merkezinden (santral) faydalanırım. 
v. Kütahya Belediyesinin dilek ve şikayet kutularını işe yarar buluyorum.

vi. Belediyede vatandaşın istek ve şikayetlerini bildirebileceği "Beyaz Masa" isminde bir birimin olduğunu daha önce duydum.

vii. Belediyeyle ilgili herhangi bir isteğim ya da şikayetim olduğunda "Beyaz Masa"dan faydalanırım.

Çalışmada kurulan hipotezlerden; "H1a=Halkla İlişkiler Boyutlarından Tanıma'nın Kurumsal İtibar üzerinde pozitif etkisi vardır." Hipotezi ile "H1b= Halkla İlişkiler Boyutlarından Tanıtma'nın Kurumsal İtibar üzerinde pozitif etkisi vardır." Hipotezi kabul edilerek Halkla ilişkiler boyutlarından tanıma ve tanıtma boyutlarının pozitif yönde etkisi olduğuna ulaşılmıştır.

Yapılan araştırmada halkla ilişkiler boyutlarından tanıtmanın kurumsal itibar üzerinde etkisinin son derece önemli olduğu görülmektedir. Çünkü tanıtma kurumun; faaliyetlerini hizmetlerini, olumlu yönlerini hedef kitleye aktarma kısacası reklam yapmaktır. Dolayısıyla tanıtma faaliyetlerine kurum ne kadar önem verirse hedef kitledeki itibarı, saygınlığı, imajı o derece pozitif yönde artacaktır. Halkla ilişkiler boyutlarından tanıma ise tanıtma boyutuna göre etkisi az olmakla birlikte kuruluş tarafından önemsenecek seviyede bulunmaktadır. Tanıma kuruluşun hedef kitle tarafindan bilinebilirlik düzeyidir. Diğer bir deyişle hedef kitle kuruluş hakkında ne kadar bilgiye sahip, kuruluşun amacını, hedefini, görevini, özelliklerini, sunduğu hizmetleri hangi bildiği ile ilgilidir. Dolayısıyla tanıma itibar ile bağlı bir boyuttur. Çünkü hedef kitle itibarlı olarak gördükleri kuruluşları daha iyi araştırma yoluna giderler. Onun kimliğini, özelliklerini, hedeflerini, faaliyetlerini, hizmetlerini daha çok merak ederler. Dolayısıyla itibar dolaylı olarak yine kuruluşu etkileyecek güce sahip bir durumdadır. Kısacası kuruluşlar halkla ilişkiler faaliyetlerine önem vermek zorundadırlar. Çünkü halkla ilişkiler faaliyetleri kurumsal itibar ile sıkı bir ilişki içerisindedir. Ve her kuruluşun hedefleri arasında kesinlikle hedef kitle üzerinde iyi bir itibar sahibi olmak vardır. Ve bu iyi itibara ulaşmanın en önemli yollarından birisi de halkla ilişkiler faaliyetlerine önem vermek, halkla ilişkiler faaliyetlerini sürekli olarak geliştirmekten geçmektedir.

Sonuç olarak kurumların en büyük sermayelerinin itibarları olduğu bilinen bir gerçek olmakla birlikte bu sermayeye sahip olabilmek, onu artırarak sürdürebilmek için kurumlar hedef kitleleriyle irtibatı sağladıkları halkla ilişkiler birimlerine ve uygulamalarını son derece büyük önem vermeleri önerilmektedir. Çünkü varlığını en faydalı şekilde sürdürmek isteyen bir insan için dili ne anlam ifade ediyorsa ise kurum ve kuruluşlar için de halkla ilişkiler birimi aynı anlamı ifade etmektedir. İnsanoğlu kendini en iyi şekilde ifade edebilmek için dilini en iyi şekilde kullanmaya çalışırken kurumlarda kendilerini en iyi şekilde ifade etme arzularından dolayı halkla ilişkiler uygulamalarını etkili ve verimli bir şekilde kullanmaları hususu üzerinde durulması gereken önemli bir konudur. Çünkü kurumlar açısından hedefe ulaşmanın en önemli yolu iyi bir itibardır, iyi bir itibarın en etkili yolu ise iyi bir halkla ilişkilerdir.

Bundan sonraki çalışmalarda "Kurumsal Sosyal Sorumluluk Faaliyetlerinin Kurumsal İtibar Üzerindeki Etkisi” ile ilgili yapılacak çalışmanın bilime ve ilgililere, hem de topluma faydalı olacağı düşünülmektedir. Çünkü kurum ve kuruluşlar rakiplerine oranla daha etkili ve farklı olabilmek için kurumsal itibarın yönetimine önem vererek, hassas bir çarpan olan kurumsal itibarın değerini anlamaya başlamışlardır. Kurumsal sosyal sorumluluk hedef kitle algısında kurum açısından etki yaratabilecek bir unsur olduğundan dolayı kurumsal sosyal sorumluğun öneminin anlaşılması, uygulanırlılığının arttırılması ve faydalı bir şekilde yürütülmesi kurumsal itibarın kazanılmasında önemli bir değişken olacağ düşünülmektedir. 


\section{Kaynakça}

Akbulut, E. (2011). "Sivil Toplum Kuruluşlarının Kurumsal İtibar Yönetimi Sürecinde Halkla İlişkiler Uygulamalarının Rolü”, Doktora Tezi, Ege Üniversitesi Sosyal Bilimler Enstitüsü, İzmir.

Altıntaş, E. (2005). “Kurumsal İtibar ve Anadolu Üniversitesi İ.B.F. Örneği”, Yüksek Lisans Tezi, Anadolu Üniversitesi Sosyal Bilimler Enstitüsü, Eskişehir. https://doi.org/10.5152/rss.2019.0008

Altunışık, R., Çoşkun, R., Bayraktaroğlu S. ve Yıldırım, E. (2007). Sosyal Bilimlerde Araştırma Yöntemleri SPSS Uygulamaları, Sakarya Yayınc1lık, Sakarya.

Argüden, Y. (2003). İtibar Yönetimi, Arge Danışmanlık Yayınları, İstanbul.

Arıkan, S. (2001). Liderlik (Yönetim ve Organizasyon İçinde), Nobel Yayınları, Ankara.

Asna, A. (1998). Public Relations Temel Bilgiler, Der Yayınevi, Yayın No:112, İstanbul.

Aydın, F. (2012), "Halkla İlişkiler Perspektifinden Kurum İmajının Tüketici Davranışına Etkisi IKEA Örneği”, Yüksek Lisans Tezi, Başkent Üniversitesi Sosyal Bilimler Enstitüsü, Ankara. https://doi.org/10.1501/sbeder_0000000047

Bakır Kurt, N. (2015). "Sağlık Kurumlarında Halkla İlişkiler Uygulamaları”, Yüksek Lisans Tezi, Beykent Üniversitesi Sosyal Bilimler Enstitüsü, İstanbul. https://doi.org/10.11616/basbed.vi.480943

Barnett, M.L., Jermier, J.M. ve Lafferty, B. A. (2006). "Corporate Reputation: The Definitional Landscape”, Corporate Reputation Review 9(1): pp.26-38. https://doi.org/10.1057/palgrave.crr.1550012

Bozkurt, M. (2011), "Balıkesir Üniversitesi Sosyal Bilimler Enstitüsü Turizm İşletmeciliği ve Otelcilik Anabilim Dalı Kurumsal İtibar Yönetiminin Müsşeri Değerlendirme Sürecine Yansıması ve Etkileri: Konaklama İşletmelerine Yönelik Bir Uygulama” Doktora Tezi, Balıkesir Üniversitesi Sosyal Bilimler Enstitüsü, Balıkesir. https://doi.org/10.31795/baunsobed.645355

Budak, G. ve Budak, G. (2004). Halkla İlişkiler Davranışsal Bir Yaklaşım, Barış Yayınları, İzmir

Budak, G. ve Budak, G. (2010). İmaj Mühendisliği Vizyonundan Halkla İlişkiler, Barış Yayınları, İzmir

Chun, R. (2005). "Corporate Reputation: Meaning and Measurement", International Journal of Management Reviews, c.7(2), pp.91-109.

Dalton, J. ve Croft, S. (2003). Managing Corporate Reputation: A Specially Commissioned Report, London, UK: Thorogood.

Demirci, M.K. ve Güler, M. (2015). "Beklenen ve Algılanan Kalite Düzleminde Hastanelerde İç Müşteri İlişkisinin Dış Müşteriye Yansıması" 14. Ulusal İşletmecilik Kongresi Bildiriler Kitabi Cilt 1, sayfa (746 - 757)

Dowlıng, G. (2001). Creating Corporate Reputations, Identity, Image and Performance, Oxford University Press, New York U.S.A.

Eğinli, A. (2008). Farklılaşma Çağında Kurumsal Başarıyı Yakalamak, Nobel Yayın Dağıtım, Ankara.

Erdem, A. ve Akbaba, E. (2007). Halkla ilişkiler Nedir Ne Değildir?, Eğitim Kitabevi Yayınları, Konya. 
Erdoğan, İ. (2005). İletişimi Anlamak, Ankara.

Erhan, T. (2013). "Turizm İşletmelerinde Kurumsal İtibar Algısı: Antalya Bölgesindeki Beş Yıldızlı Otel Müşterileri Üzerine Bir Araştırma", Yüksek Lisans Tezi, Süleyman Demirel Üniversitesi Sosyal Bilimler Enstitüsü, Isparta. https://doi.org/10.14520/adyusbd.572941

Ergun, D. (2012). "Çağdaş Yönetim Konuları", İşletme Yönetimi, Barış, BARAZ ve Nurhan, ŞAKAR, (Ed.), Anadolu Üniversitesi yayınları, Eskişehir.

Fombrun, C. J. ve BOSS Christopher, B. (2001). "The Reputation Quotient, Part:1 Developing a Reputation Quotient, The Gague Delahaye Medialink's”, Newsletter of Worldwide Communications Research, Volume:14, No:3.

Freitag, A.R. ve Quesinberry Stokes, A. (2009). Global Public Relations Spaning Borders, Spannig Cultures, ABD.

Genç, N. (2012). Yönetim ve Organizasyon: Çağdaş Sistemler ve Yaklaşımlar, Seçkin Yayıncılık, 4. Bask1, Ankara.

Gezmen, A. (2014). "Kurumsal İtibar Yönetimi ve Kurumsal İtibar Algısının Ölçülmesine Yönelik Bir Araştırma: Türkiye Büyük Millet Meclisi Örneği”, Yüksek Lisans Tezi, Türk Hava Kurumu Üniversitesi, Sosyal Bilimler Enstitüsü, Ankara. https://doi.org/10.14520/adyusbd.572941

Güler, M., Çetin, M.S., Baran, A., Demirci, M.K., Kırmızı, C. ve Budak, S. (2015). "The Contributions of Corporate Social Responsibility Prjects to Corporate Reputation" The Macrotheme Review, 4(8), pp. 3

Gümüş, M ve ÖKSÜZ, B. (2009). Turizm İşletmelerinde Kurumsal İtibar Yönetimi, Nobel Yayınc1lık, Ankara.

Hutton, J. G., Goodman, M. B., Alexander, J. B. ve Genest, C. M. (2001). "Reputation Management: The New Face of Corporate Public Relations?", Public Relations Review, 27, pp.247-261. https://doi.org/10.1016/s0363-8111(01)00085-6

İcil, A. (2008). "Akademik Örgütlerde Kurumsal İtibar ve İletişim İlişkisi: Akdeniz Üniversitesi Üzerine Bir Araştırma", Yüksek Lisans Tezi, Akdeniz Üniversitesi Sosyal Bilimler Enstitüsü, Antalya. https://doi.org/10.31123/akil.463240

Kadıbeşgil, S. (2007). İtibar Yönetimi, MediaCat, İstanbul.

Kadıbeşgil, S. (1986). Halkla İlişkilerde Temel İlkeler, Tükelman A.Ş. Basımevi, İzmir.

Kadıbeşgil, S. (2001). "Halkla İlişkilere Nereden Başlamalı?”, MediaCat, 4. Baskı, ss. 41-42.

Karaköse, T. (2006). "Eğitim Örgütlerindeki İç ve Dış Paydaşların Kurumsal İtibara İlişkin Algılamaları", Yayınlanmış Doktora Tezi, Fırat Üniversitesi Sosyal Bilimler Enstitüsü, Elazığ.

Karaköse, T. (2007). Kurumların DNA'sı İtibar ve Yönetimi, Nobel Yayın Dağıtım, 1. Basım, Ankara.

Köker, N.E. (2010). “Kurum Değeri Yaratma ve Geliştirmede İtibar Yönetiminin Önemi”, Doktora Tezi, Ege Üniversitesi Sosyal Bilimler Enstitüsü, İzmir.

Kuş, A. (2008). "Yerel Yönetimlerde Halkla İlişkiler: Kocaeli Büyükşshir Belediyesi’nin Yerel Basına Yansıması", Yüksek Lisans Tezi, Kocaeli Üniversitesi, Sosyal Bilimler Enstitüsü, Kocaeli. https://doi.org/10.30803/adusobed.356139 
Martin G. ve S. Hetrick, (2006). Corporate Reputations, Branding and People Management: A Strategic Approach to HR, Burlington: Butterworth-Heineman Publications.

Okay, A. (2005a). Halkla İlişkiler, Der Yayınları, İstanbul.

Okay, A. (2005b). Kurum Kimliği, Mediacat, İstanbul.

Okay, A. ve OKAY, A. (2005). Halkla İlişkiler Kavram, Strateji ve Uygulamaları, Der Yayınları, Genişletilmiş 2.Basım, İstanbul.

Oktay, M. (2002). Politikada Halkla İlişkiler, Derin Yayınları, İstanbul.

Ordu, M. (2015). "İş Ahlakının Kurumsal İtibar Üzerindeki Etkisine Yönelik Bir Araştırma”, Yayınlanmamış Yüksek Lisans Tezi, Dumlupınar Üniversitesi Sosyal Bilimler Ünstitüsü, Kütahya. https://doi.org/10.17218/hititsosbil.427459

Öncel, M. (2010). "Sürdürülebilir Rekabet Üstünlüğü Sağlamada Kurumsal İtibar Yönetimi: Yüksek Öğretimde Yapılandırılmasına Yönelik Bir Model Önerisi”, Doktora Tezi, Dumlupınar Üniversitesi, Sosyal Bilimler Enstitüsü, Kütahya. https://doi.org/10.29029/busbed.373709

Peltekoğlu Balta, F. (1993). Halkla İlişkiler Giriş, Marmara Üniversitesi İletişim Fakültesi Yayın No:1, İstanbul. https://doi.org/10.18094/josc.596295

Peltekoğlu Balta, F. (2007). Halkla İlişkiler Nedir? Beta Basım Yayım Dağıtım, Yayın No:1736, İstanbul.

Post, J. ve Grıffin, J. (1997). "Corporate Reputation and External Affairs Management”, Corporate Reputation Review, 1, pp.165-171. https://doi.org/10.1057/palgrave.crr.1540038

Sadedil, S.N. (2011). "Bir Etnik Gruba Yönelik Pazarlama Faaliyetlerinin Kurumsal İtibar Üzerine Etkisi”, Yüksek Lisans Tezi, Yeditepe Üniversitesi Sosyal Bilimler Enstitüsü, İstanbul. https://doi.org/10.14520/adyusbd.572941

Sarıkaya, M. ve Oruç, İ. (2010). "Kurumsal İtibar Oluşturmada Stratejik İşbirliği Olarak İşletmeSTK İlişkisi”, Organizasyon ve Yönetim Bilimler Dergisi, Cilt: 2, Sayı: 2, ss. 95-102. https://doi.org/10.18657/yonveek.335255

Tortop, N. (2003). Halkla İlişkiler, Yargı Yayınevi, Yayın No:18, Ankara.

Tüysüzoğulları, E. (2010). "Ortaöğretim Kurumlarında Yönetici ve Öğretmenlerin Kurumsal İtibara İlişkin Algılamaları: Kastamonu Uygulaması", Yüksek Lisans Tezi, Dumlupınar Üniversitesi Sosyal Bilimler Enstitüsü, İşletme Anabilim Dalı, Kütahya. https://doi.org/10.5152/dcbybd.2018.1683

Üçok, I. D. (2008). "Kalite Odaklı Yönetimin Kurumsal İtibar Yaratmadaki Rolü, Önemi ve Reptrack İtibar Endeksi Yardımıyla Bir Uygulama", Yüksek Lisans Tezi, Marmara Üniversitesi Sosyal Bilimler Enstitüsü, İstanbul. https://doi.org/10.14520/adyusbd.572941

Ülger, B. (2003). İşletmelerde İletişim ve Halkla İlişkiler “The Big Busıness”, Der Yayınları, Yayın No: 365, İstanbul.

Yirmibeş, S. (2010). "Kurumsal İtibar Yönetimi ve Kamuya Bağlı Bir Kurumda Kurumsal İtibarın Ölçülmesi Üzerine Bir Araştırma", Yüksek Lisans Tezi, Dokuz Eylül Üniversitesi Sosyal Bilimler Enstitüsü, İzmir. https://doi.org/10.14520/adyusbd.572941 


\section{Elektronik Kaynaklar}

Argüden, Y. (2002). "Kurumsal Sosyal Sorumluluk", http://www.arguden.net/ arguden/ UserFiles/File/kitaplar/ kurumsalsosyalsorumluluk.pdf, (02.02.2016).

https://kemaldoymus.files.wordpress.com/2009/12/korelasyon.ppt (28.01.2016).

Kadıbeşgil, S. “İtibarınızı Yönetmekten Daha Önemli Bir İşiniz Var mı?", http://www.orsa.com.tr/cgibin/asp/content.asp?type=normal\&lang=TR\&id=15(19.02.2016. 